\title{
Involvement of nuclear factor kappa B in the regulation of rat luteal function: potential roles as survival factor and inhibitor of $20 \alpha$-hydroxysteroid dehydrogenase
}

\author{
C M Telleria ${ }^{1}$, A A Goyeneche ${ }^{1}$, C O Stocco and G Gibori \\ Department of Physiology and Biophysics, University of Illinois, Chicago, Illinois 60612, USA \\ ${ }^{1}$ Division of Basic Biomedical Sciences, University of South Dakota School of Medicine, Vermillion, South Dakota 57069, USA
}

(Requests for offprints should be addressed to G Gibori; Email: ggibori@uic.edu)

\begin{abstract}
Nuclear factor kappa B (NFkB) is an important intracellular conveyor of extracellular signals and modulates a number of gene responses. Due to the potential significance of $\mathrm{NF} \mathrm{KB}$ in regulating ovarian gene expression, we examined in the rat: (i) whether NFKB is activated and developmentally regulated in the corpus luteum $(\mathrm{CL})$ throughout pregnancy; (ii) the proteins forming the NFKB complex in luteal cells; and (iii) the role of this transcription factor in luteal function. Western analysis and immunohistochemistry revealed that p65 and p50 were highly expressed throughout pregnancy and were located in both the nucleus and cytoplasm of luteal cells. In addition, because NFKB is maintained in the cytoplasm bound to I $\mathrm{KB}$, whose phosphorylation allows $\mathrm{NF} \kappa \mathrm{B}$ translocation to the nucleus, we studied the developmental expression of phosphorylated and nonphosphorylated forms of $I \kappa B \alpha$. Western analysis revealed that $I \kappa B \alpha$ was present and phosphorylated throughout pregnancy in the $C L$ whereas by protein/DNA array and electromobility shift assays we found that luteal nuclear extracts bind to an NFKB consensus sequence, and that the binding activity decreased along pregnancy. The specific binding was supershifted only by an anti-p65 antibody and not by antibodies against p50, p52, cRel, or RelB. Using day 4 postpartum ovaries, we found higher NFKB binding activity in the newly formed CL than in old CL of pregnancy. Furthermore, NFKB DNA binding activity was enhanced by prolactin in luteinized granulosa cells. In our first functional study, blockade of NFKB/p65 binding to DNA with the sesquiterpene lactone helenalin in luteinized granulosa cells correlated with induction of cell death in a dose-dependent manner. In a second functional study, overexpression of $\mathrm{NF \kappa B} / \mathrm{p} 65$ in luteal cells resulted in inhibition of 20a-hydroxysteroid

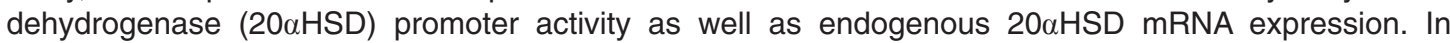
summary, we have shown that: (i) NFKB is expressed within the CL, primary luteinized granulosa cells, and a rat luteal cell line; (ii) NFKB activation within the $C L$ is developmentally regulated in pregnancy, depends on the age of the gland, and can be upregulated by prolactin; (iii) inhibition of NFKB/p65 binding to an NFKB DNA consensus sequence correlates with induction of cell death in ovarian luteinized granulosa cells; and (iv) overexpression of NFKB in luteal cells inhibits 20aHSD gene expression. The results further support a role for NFKB as a survival factor in the CL.
\end{abstract}

Journal of Molecular Endocrinology (2004) 32, 365-383

\section{Introduction}

Nuclear factor kappa B (NFkB) proteins are an important class of transcriptional regulators that affect expression of genes involved in the immune and inflammatory responses, cell growth and differentiation, and apoptosis (Blackwell \& Christman 1997, Delfino \& Walker 1999, Mercurio \& Manning 2000). The NFкB family is composed of five mammalian homologous, cRel, RelA (p65), RelB, p50/p105 (NFkB1), and p52/p100 (NFкB2). $\mathrm{NF \kappa B}$ proteins form an array of homo- and 
hetero-dimers (Mercurio \& Manning 2000). The classic NFKB transcriptional activator is a heterodimer composed of p65 and p50. In most cells, NFKB exists as an inactive form found predominantly in the cytoplasm bound to the inhibitory proteins IкBs (Siebenlist et al. 1994, Baldwin 1996). The main role of I $\kappa B$ is to maintain cytoplasmic localization of $\mathrm{NF} \kappa \mathrm{B}$ dimers and to inhibit $\mathrm{NF} \kappa \mathrm{B}$ binding to DNA both by masking the DNA-binding regions of the NFKB dimers and by promoting nuclear export of NFkB. Nuclear translocation of transcriptionally active $\mathrm{NF \kappa B}$ dimers is induced by stimulation of cells with a large array of NFKB inducers, damaging agents, and oxidative stress (Siebenlist et al. 1994). These stimuli initiate the activation of signal transduction pathways that culminate in the phosphorylation of $\mathrm{I} \kappa \mathrm{B}$ at amino-terminal serine residues by the I $\mathrm{B}$ kinase complex. Phosphorylation of $\mathrm{I} \kappa \mathrm{B}$ targets it for ubiquitination and subsequent degradation by the $26 \mathrm{~S}$ proteasome. Degradation of $\mathrm{I} \kappa \mathrm{B}$ allows import and accumulation of $\mathrm{NF \kappa B}$ binding within the nucleus, and activation of target gene expression (Delfino \& Walker 1999).

Whereas NFKB has been shown to be involved in the transcriptional regulation of genes within cells of the immune system (Blackwell \& Christman 1997), less information is available on the expression, activation status, and physiological roles of this transcription factor in reproductive tissues. One of the primary reports in this matter demonstrated a stage-specific nuclear expression of NFKB in the mammalian testis (Delfino \& Walker 1998). These authors showed nuclear expression of $\mathrm{NF \kappa B}$ in Sertoli and germ cells in a stage-specific manner, suggesting a role for this transcription factor in regulating spermatogenesis. In mouse mammary gland it was shown that NFкB activity was developmentally regulated, increasing during pregnancy and declining with the onset of lactation (Geymayer \& Doppler 2000). In the human endometrium, a role for NFKB has been attributed during menstrual induction (Brenner et al. 2002). In rat ovarian granulosa cells $\mathrm{NF \kappa B}$ was activated by follicle-stimulating hormone (Wang et al. 2002) and prevented apoptosis induced by tumor necrosis factor- $\alpha$ (TNF- $\alpha$ ) (Xiao et al. 2001). The NFкBmediated antiapoptotic effect in granulosa cells appears to involve the stimulation of at least two antiapoptotic proteins: X-linked inhibitor of apoptosis (Xiap) (Xiao et al. 2001), a direct inhibitor of executioner caspase-3 and caspase-7 (Tamm et al. 2003), and Flice-like inhibitor protein (FLIP) (Xiao et al. 2002), an inhibitor of death receptor-mediated activation of caspase-8 (Krueger et al. 2001). In human ovarian epithelial cancer cells, a role for $\mathrm{NF} \kappa \mathrm{B}$ has been proposed as mediator of resistance to apoptosis induced by TNF- $\alpha$ (Xiao et al. 2003). In the corpus luteum, there is little information regarding the expression and function of NFאB. A moderate expression of $\mathrm{NF \kappa B}$ in the human corpus luteum, which remained relatively constant throughout the luteal phase, was recently reported (Vaskivuo et al. 2002). It is not yet known, however, whether NFKB is activated during luteal development, what are the members of the NFKB family of proteins forming the NFKB complex in luteal cells, and what role this transcription factor may have in regulating luteal function.

In the present studies we have examined the expression and activation status of $\mathrm{NF \kappa B}$ in the rat corpus luteum during development along pregnancy, and defined the luteal NFKB subunits having DNA binding capacity. We have also determined that $\mathrm{NF} \kappa \mathrm{B}$ activation is regulated by the main tropic hormone in the rat corpus luteum, i.e. prolactin (PRL) (Risk \& Gibori 2001), and have shown that $\mathrm{NF \kappa B}$ may be involved in the regulation of luteal apoptosis and in the expression of the 20a-hydroxysteroid dehydrogenase (20 $\alpha$ HSD) gene, which encodes for a key enzyme that metabolizes progesterone during luteal regression (Wiest et al. 1968, Albarracin et al. 1994).

\section{Materials and methods}

\section{Chemicals}

DMEM/F12 (1:1), RPMI 1640, nonessential amino acids, sodium pyruvate, trypsin-EDTA, antibiotics and antimycotics were purchased from Mediatech (Herndon, VA, USA). Fetal bovine serum (FBS) was from Hyclone Laboratories Inc. (Logan, UT, USA). Ovine PRL (oPRL) (PRL-18, $30 \mathrm{IU} / \mathrm{mg}$ ) was from NIDDK (NIH, Bethesda, MD, USA). Helenalin was from Biomol Research Laboratories Inc. (Plymouth Meeting, PA, USA). The oligonucleotides used in the RT-PGR and electromobility shift assays (EMSAs) were obtained from Invitrogen Life Technologies Inc. (Frederik, MD, USA). Aprotinin and protease inhibitor cocktail tablets were from Roche Diagnostics 
GmbH (Mannheim, Germany). $\left[\gamma_{-}{ }^{32} \mathrm{P}\right] \mathrm{ATP}$ and $\left[\alpha_{-}{ }^{32} \mathrm{P}\right] \mathrm{dCTP}$ were purchased from Amersham Biosciences Corp. (Piscataway, NJ, USA). PMSG, human chorionic gonadotropin (hCG), 0.45\% D-glucose, EGTA, Hepes, sucrose, dithiothreitol, leupeptin, pepstatin-A, phenylmethylsulfonyl fluoride, and all other reagent grade chemicals were obtained from Sigma Chemical Co. (St Louis, MO, USA). Nuclear extracts derived from treated phorbol 12-myristate 13-acetate (TPA) Jurkat cells were purchased from Geneka Biotechnology Inc. (Montreal, Quebec, Canada).

\section{Animals and tissue preparation}

Pregnant (day $1=$ sperm-positive), adult males, and immature female (day 25 of age) Sprague-Dawley rats were obtained from Sasco Animal Labs (Madison, WI, USA). The animals were housed at $22-24{ }^{\circ} \mathrm{C}$ on a $14 \mathrm{~h}$ light: $10 \mathrm{~h}$ darkness cycle and allowed free access to standard rat chow and water. All experiments were conducted in accordance with the principles and procedures of the NIH Guide for the Care and Use of Laboratory Animals and were approved by the University of Illinois Animal Care and Use Committee. For the developmental studies, rats were killed at various stages of pregnancy from day 7 to day 21 (the day before parturition), and on day 4 after parturition. Corpora lutea were dissected from the ovaries under a stereoscopic microscope. On day 4 postpartum the isolated corpora lutea were classified as old (i.e. corpora lutea of the previous pregnancy) or new (i.e. newly formed corpora lutea after postpartum ovulation) as previously reported (Goyeneche et al. 2003a). Spleen, prostate and epididymis were obtained from three different male rats. All tissues were frozen in liquid nitrogen and stored at $-80{ }^{\circ} \mathrm{C}$ until processed for protein isolation. For the immunohistochemical studies whole ovaries from pregnant (day 15) animals were obtained and fixed for $1 \mathrm{~h}$ at room temperature in a solution of $10 \%(\mathrm{v} / \mathrm{v})$ phosphate-buffered neutral formalin, dehydrated in ethanol series, cleared in xylene, and embedded in paraffin. To determine the effect of lipopolysaccharide (LPS) in vivo on NFкB activation animals were injected i.p. with either $5 \mathrm{mg}$ LPS (E. coli 055:B5; Sigma) or vehicle on day 9 of pregnancy, and were killed $1 \mathrm{~h}$ later. Corpora lutea were isolated, frozen in liquid nitrogen, and stored at $-80{ }^{\circ} \mathrm{C}$ until protein isolation.

\section{Primary luteinized granulosa cells}

Twenty-five-day-old immature rats were treated with 15 IU PMSG i.p. followed 2 days later by 15 IU hCG i.p. Eight hours after hCG injection, follicles were incubated sequentially in DMEM/ F12 (1:1) containing respectively $6 \mathrm{mM}$ EGTA and $0.5 \mathrm{M}$ sucrose, and luteinized granulosa cells were harvested by needle pricking the follicles. The cells were cultured for $72 \mathrm{~h}$ at $37^{\circ} \mathrm{C}$ in an atmosphere consisting of $5 \% \mathrm{CO}_{2} / 95 \%$ air in DMEM/F12 (1:1) with $15 \mathrm{mM}$ Hepes, $1 \% \mathrm{FBS}$, and $100 \mathrm{IU} / \mathrm{ml}$ penicillin $\mathrm{G}, \quad 100 \mu \mathrm{g} / \mathrm{ml}$ streptomycin, and $0.25 \mathrm{mg} / \mathrm{ml}$ amphotericin B. Medium was then replaced and cells were treated as depicted in figure legends. To evaluate the morphology of the luteinized granulosa cells in situ, cells were fixed in $4 \%$ paraformaldehyde and stained with 4',6diamidino-2-phenylindole dihydrochloride (DAPI) (Roche). Alteration of the chromatin was observed using a Leica DM/IRB microscope (Leica Microsystems, Bannockburn, IL, USA).

\section{Luteal cell line}

The simian virus 40-transformed temperaturesensitive rat luteal cell line GG-CL was used (Sugino et al. 1998a). Cells were cultured under 5\% $\mathrm{CO}_{2} / 95 \%$ air in RPMI 1640 medium supplemented with $1 \times$ glutamine, $2 \times$ antibioticantimycotic solution, $1 \times$ nonessential amino acids, $1 \times$ sodium pyruvate, $0.45 \% \mathrm{D}$-glucose, and $10 \%$ FBS. Cells were cultured at $33{ }^{\circ} \mathrm{C}$ to $60 \%$ confluence and differentiated at $39^{\circ} \mathrm{C}$ over $48 \mathrm{~h}$ before harvesting.

\section{Western blot analysis}

Isolated corpora lutea, prostate, epididymis, and spleen were homogenized in $2 \mathrm{ml}$ ice-cold homogenization buffer containing $25 \mathrm{mM}$ Tris- $\mathrm{HCl}$ (pH 7·4), $2 \mathrm{mM} \mathrm{MgCl}_{2}, 1 \mathrm{mM}$ EDTA, $1 \mathrm{mM}$ phenylmethylsulfonyl fluoride, $1 \mathrm{mM}$ dithiothreitol, $1 \mu \mathrm{M}$ leupeptin, $1 \mu \mathrm{M}$ pepstatin-A, and $1 \mu \mathrm{g} / \mathrm{ml}$ aprotinin. Homogenates were assayed for protein content by the Lowry method, appropriately diluted in $6 \times$ concentrated electrophoresis sample buffer, boiled for $10 \mathrm{~min}$, and stored at $-80^{\circ} \mathrm{G}$ until electrophoresed. Equivalent amounts of protein $(50 \mu \mathrm{g})$ were separated through 8\% SDS-PAGE gels and electrotransferred to nitrocellulose membranes (Schleicher \& Schuell Inc., 
Keene, NH, USA). Immunoblotting was performed by blocking nonspecific binding with 5\% nonfat milk in Tris-buffered saline (TBS) $(0.15 \mathrm{M} \mathrm{NaCl}$, $0.05 \mathrm{M}$ Tris, $\mathrm{pH} 7 \cdot 6$ ) containing $0 \cdot 1 \%$ Tween 20. Blots were then incubated overnight with 0.5 $1 \mu \mathrm{g} / \mathrm{ml}$ of the following antibodies (all obtained from Santa Cruz Biotechnology, Santa Cruz, CA,

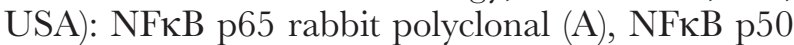
(H-119) rabbit polyclonal, I $\mathrm{B} \alpha$ rabbit polyclonal $(\mathrm{C}-21)$ and $\mathrm{p}-\mathrm{I} \kappa \mathrm{B} \alpha$ mouse monoclonal (B-9). The membranes were washed and incubated with a secondary antibody (goat anti-rabbit or goat anti-mouse; 1:1000 dilution) linked to horseradish peroxidase (HRP) (Dako Corp., Carpinteria, CA, USA) for $90 \mathrm{~min}$. After extensive washing, blots were developed by chemiluminescence and exposed for 15-120 s to X-ray films. The molecular size of immunoreactive bands was estimated by the co-migration of a prestained SDS-PAGE molecular mass standard (Benchmark; Gibco BRL, Gaithersburg, MD, USA).

\section{Immunohistochemistry}

Serial paraffin sections $5 \mu \mathrm{m}$ thick were mounted on 3-aminopropyltriethoxysilane-coated slides. The immunohistochemical procedure was performed using a highly sensitive strept ABComplex/HRP detection system (Dako). The sections were deparaffinized with xylene and rehydrated in alcohol solutions of increasing water content, then washed in TBS. Endogenous peroxidases were blocked in $3 \% \quad \mathrm{H}_{2} \mathrm{O}_{2}$ for $20 \mathrm{~min}$ at room temperature. To reduce nonspecific background staining, the sections were blocked with 3\% normal goat serum for $20 \mathrm{~min}$. The sections were then incubated with the anti-NFкB p65 antibody (Santa Cruz Biotechnology; $1 \mu \mathrm{g} \operatorname{IgG} / \mathrm{ml}$ ) overnight at $4{ }^{\circ} \mathrm{C}$ in a moist incubation chamber. The sections were washed in TBS and incubated successively with biotinylated goat anti-rabbit $\operatorname{IgG}(2.5 \mathrm{mg} / \mathrm{ml}$; Dako) for $30 \mathrm{~min}$ at room temperature, and strept ABComplex/HRP (1:50 dilution) for $30 \mathrm{~min}$ at room temperature. Each incubation was followed by two $10 \mathrm{~min}$ washes in TBS. After the final wash, sections were incubated in the dark for $10 \mathrm{~min}$ with diaminobenzidine (DAB) solution $(0.05 \mathrm{M}$ Tris buffer, $\mathrm{pH} 7 \cdot 6$, containing $0.6 \mathrm{mg} / \mathrm{ml} \mathrm{DAB}$ and $0.03 \% \mathrm{H}_{2} \mathrm{O}_{2}$ ) for developing peroxidase activity. After washing with tap water the sections were counterstained with hematoxylin, dehydrated in serial alcohols to xylene, and mounted. In the negative control slides the primary antibody was replaced with TBS. The tissue samples were observed and photographed with a Zeiss IM 35 microscope (Carl Zeiss, Oberkochen, Germany).

\section{Protein/DNA array}

Activation of several transcription factors in the corpus luteum was screened using the TranSignal protein/DNA array procedure according to the manufacturer's instructions (Panomics, Inc., Redwood City, CA, USA). Activation of transcription factors other than NFKB was assessed for other studies. For the present study we focused on the binding capacity to an NFKB DNA consensus sequence of nuclear extracts obtained from corpora lutea of rats on day 5 of pregnancy. In brief, the nuclear extracts were incubated with a set of biotin-labeled DNA binding oligonucleotides, one of them containing the NFKB consensus sequence, to allow the formation of protein/DNA complexes. Then the protein/DNA complexes were separated from the free probes, and the probes in the complexes were isolated from the proteins and hybridized to the TranSignal Array (Panomics). Detection of the signals was obtained by chemiluminescence.

\section{Nuclear extract preparation and EMSAs}

To prepare nuclear cell extracts from either GG-CL cells or primary luteinized granulosa cells, $100 \mathrm{~mm}$ plates at $70-80 \%$ of confluence were used. Cells were washed in cold PBS and quickly frozen by placing the plate on dry ice. Then, plates with cells were kept at $-80{ }^{\circ} \mathrm{C}$ until nuclear extract preparation. Cells were harvested at $4{ }^{\circ} \mathrm{C}$ by scraping in $300 \mu \mathrm{l}$ solution A $(10 \mathrm{mM}$ Hepes, $\mathrm{pH} 7.9,10 \mathrm{mM} \mathrm{KCl}, 1.5 \mathrm{mM} \mathrm{MgCl}_{2}, 0.5 \mathrm{mM}$ phenylmethylsulfonyl fluoride, $0.5 \mathrm{mM}$ dithiothreitol, $1 \mu \mathrm{g} / \mathrm{ml}$ aprotinin, $1 \times$ protein inhibitor cocktail), transferred to $1.5 \mathrm{ml}$ Eppendorf tubes, and placed in an orbital rocker for $15 \mathrm{~min}$ at $4{ }^{\circ} \mathrm{C}$. After rocking, $25 \mu \mathrm{l}$ Nonidet P-40 were added and the tubes were vigorously vortexed for $30 \mathrm{~s}$. The nuclear pellet was obtained by centrifugation at $14000 \boldsymbol{g}$ at $4{ }^{\circ} \mathrm{C}$ for $1 \mathrm{~min}$ and resuspended in solution $\mathrm{B}$, which was similar to solution $\mathrm{A}$ except that it contained $420 \mathrm{mM} \mathrm{NaCl}$ and $25 \%(\mathrm{v} / \mathrm{v})$ glycerol, and lacked $\mathrm{KCl}$. The solution was 
vigorously vortexed for $30 \mathrm{~min}$ at $4{ }^{\circ} \mathrm{C}$ and then centrifuged at $14000 \boldsymbol{g}$ at $4{ }^{\circ} \mathrm{C}$ for $5 \mathrm{~min}$. The supernatant containing the nuclear extract was divided into aliquots, snap frozen in liquid nitrogen, and stored at $-80^{\circ} \mathrm{C}$. To prepare nuclear extracts from corpora lutea, $30 \mathrm{mg}$ tissue were homogenized in $200 \mu \mathrm{l}$ solution A using a Dounce homogenizer (B type pestle). The homogenate was transferred to $1.5 \mathrm{ml}$ Eppendorf tubes, placed on ice for $15 \mathrm{~min}$, and centrifuged at $400 \mathrm{~g}$ for $10 \mathrm{~min}$ at $4{ }^{\circ} \mathrm{C}$. The pellet was resuspended in $80 \mu \mathrm{l}$ solution $\mathrm{B}$, once again homogenized, rocked vigorously for $20 \mathrm{~min}$ at $4{ }^{\circ} \mathrm{C}$, vortexed for $1 \mathrm{~min}$ at $4^{\circ} \mathrm{C}$, and then centrifuged at $14000 \mathrm{~g}$ for $20 \mathrm{~min}$ at $4{ }^{\circ} \mathrm{C}$. The supernatant constituted the luteal nuclear extract. Protein concentration was determined by the bicinchoninic acid method (Pierce Biotechnology Inc., Rockford, IL, USA). The following oligonucleotides and their complements were used as probes and competitors: 5'AGGTTGGGGTATTTGGAGGGG-3' (Rel probe) and 5'-AGATTGGCATAGGTCGAGCGG-3' (mutant probe). The underlined portions represent the consensus sequences. Double-strand DNA oligonucleotides were ${ }^{32} \mathrm{P}$ labeled with $\left[\gamma_{-}{ }^{32} \mathrm{P}\right] \mathrm{ATP}$ and T4 polynucleotide kinase (Invitrogen Life Technologies, Carlsbad, CA, USA). Nuclear extracts $(3-8 \mu \mathrm{g})$ were incubated in reaction buffer (10 mM Tris- $\mathrm{mCl}, \mathrm{pH} \quad 7 \cdot 5, \quad 1.2 \mathrm{mM} \quad \mathrm{MgCl}_{2}$, $0.6 \mathrm{mM}$ EDTA, $0.5 \mathrm{mM}$ dithiothreitol, $50 \mathrm{mM}$ $\mathrm{NaCl}, 0 \cdot 25 \mu \mathrm{g} / \mu \mathrm{l}$ poly $(\mathrm{dI}-\mathrm{dC})$, and $4 \%$ glycerol) for $20 \mathrm{~min}$ at $20-22{ }^{\circ} \mathrm{C}$ in the presence or absence of excess unlabeled oligonucleotide or $1-3 \mu \mathrm{l}$ of the following specific antibodies: p65 (A), p50 (H-119), p52 (K-27), cRel (N) or Rel B (C-19) (all from Santa Cruz Biotechnology). The labeled probe was added and the incubation was continued for $20 \mathrm{~min}$ at $20-22{ }^{\circ} \mathrm{C}$. The DNA/protein complexes were separated from the unbound DNA probe by nondenaturing PAGE $(4 \%$ gel $)$ at $4{ }^{\circ} \mathrm{C}$, in Tris-borate EDTA buffer $(0.5 \times ; \mathrm{pH} 8)$ and detected by autoradiography.

\section{RNA isolation and RT-PCR analysis}

Total RNA from GG-CL cells was purified using TRIzol (Invitrogen Life Technologies) according to the manufacturer's instructions. One microgram of total RNA was reverse transcribed using the Advantage RT for PCR kit (Clontech Laboratories, Inc., Palo Alto, CA, USA). The PGR reaction to amplify the $20 \alpha \mathrm{HSD}$ mRNA was performed as described previously (Stocco et al. 2000).

\section{Transient transfection, plasmids and reporter assays}

GG-CL were trypsinized and suspended in OPTIMEM (Life Technologies Inc.) at $1 \times 10^{6}$ cells/ $0.8 \mathrm{ml}$ and transfected by electroporation with $1 \mu \mathrm{g}$ $20 \alpha$ HSD-Luc construct and $3 \mu \mathrm{g}$ of a control $\beta$-galactosidase expression vector and a different amount of RelA (p65) expression plasmid using the gene pulser (Bio-Rad, Hercules, CA, USA) at a capacitance setting of $950 \mu \mathrm{F}$ and $280 \mathrm{~V}$. The total amount of DNA per well was kept constant by the addition of an empty vector when necessary. After each electroporation, cells were pooled and resuspended in RPMI 1640 medium containing 10\% FBS and plated into six-well plates at a density of $0 \cdot 8 \times 10^{6}$ cells/well. Cells were cultured overnight and then the medium was changed to phenol red-free RPMI 1640 with 1\% FBS. Cells were maintained for a maximum of $48 \mathrm{~h}$ after electroporation. To harvest cells, each well was washed twice with ice-cold PBS. Reporter lysis buffer $(100 \mu \mathrm{l})$ (Promega, Madison, WI, USA) was added into each well; $20 \mu \mathrm{l}$ cell lysate were used to measure firefly luciferase activity driven by the $20 \alpha \mathrm{HSD}$ promoter using a luciferase reporter assay system (Promega), and $20 \mu \mathrm{l}$ cell lysate were used to measure $\beta$-galactosidase activity using a luminescence $\beta$-galactosidase detection kit (Clontech). Measurements were conducted in a Lumat LB 9507 Luminometer (EG \& G Berthold, Oak Ridge, TN, USA). Relative light units were obtained by dividing the luciferase activity by the $\beta$-galactosidase activity. The 20aHSD-Luc construct used contains a $2 \cdot 5 \mathrm{~kb}$ 5 ' flanking region of the rat ovarian $20 \alpha$ HSD gene fused with a luciferase reporter plasmid (pGL3Basic; Promega) (Zhong et al. 1998). The pSV- $\beta$ galactosidase control vector was commercially obtained (Promega), whereas the RelA (p65) expression vector was kindly provided by Dr J Anrather (Beth Isreal Deaconess Medical Center, Harvard Medical School, Boston, MA, USA).

\section{Results}

\section{$\mathrm{NF} \kappa \mathrm{B} / \mathrm{p} 50$ and $\mathrm{p} 65$ proteins are expressed in the corpus luteum throughout pregnancy}

To explore the potential role of $\mathrm{NF \kappa B}$ in the function of the corpus luteum, the expression of the 
best-characterized NFкB components essentially present in all cells, the p65 and p50 proteins (Siebenlist et al. 1994, Delfino \& Walker 1999), was studied by Western analysis in total protein extracts obtained from corpora lutea of rats on different days of pregnancy. In the corpus luteum, the antibodies recognized proteins of the same sizes as those found in spleen, which was used as positive control tissue (Zhou et al. 2003). Other tissues included in the study, such as prostate, expressed only p50, whereas epididymis displayed a higher expression of p65 than p50 (Fig. 1A). In addition, both p65 and p50 proteins were highly expressed in the corpus luteum throughout pregnancy (Fig. 1B).

\section{NFкB proteins have cytoplasmic and nuclear localization within the luteal cells}

In order to define the state of activation of $\mathrm{NF \kappa B}$, the localization of the proteins within the luteal cells was established. Both p65 and p50 were mainly located within the cytoplasm of the luteal cells and showed some nuclear localization as well, with no staining whatsoever in the membrane fraction (Fig. 2A). These results were confirmed by immunohistochemistry using an antibody capable of recognizing the p65 protein. The results presented in Fig. 2B showed nuclear as well as cytoplasmic localization for p65 in luteal cells, whereas the endothelial cells surrounding the capillaries did not stain for the protein. The pattern of intracellular localization, however, varied among luteal cells. Some luteal cells showed more intense nuclear staining compared with its cytoplasmic counterpart, other cells showed only cytoplasmic staining, whereas some cells showed comparable nuclear and cytoplasmic immunostaining.

\section{Nuclear extracts obtained from luteal cells are capable of binding an NFKB consensus sequence}

Once the intracellular localization of NFKB was demonstrated, we examined the expression of phosphorylated and unphosphorylated ІкB. ІкB maintains the transcription factor $\mathrm{NF} \kappa \mathrm{B}$ within the cytoplasm, but once phosphorylated allows its translocation to the nucleus (Siebenlist et al. 1994, Delfino \& Walker 1999, Mercurio \& Manning 2000). Constitutive luteal expression of both unphosphorylated and phosphorylated I $\mathrm{I} \mathrm{B} \alpha$ was
A

\section{Tissue Specificity}

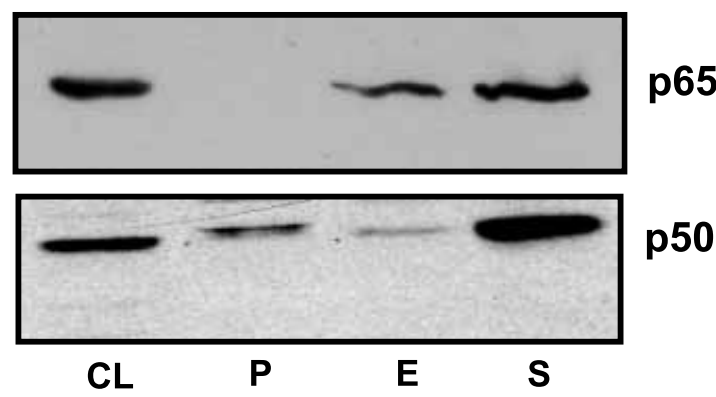

B

\section{CL : Developmental}

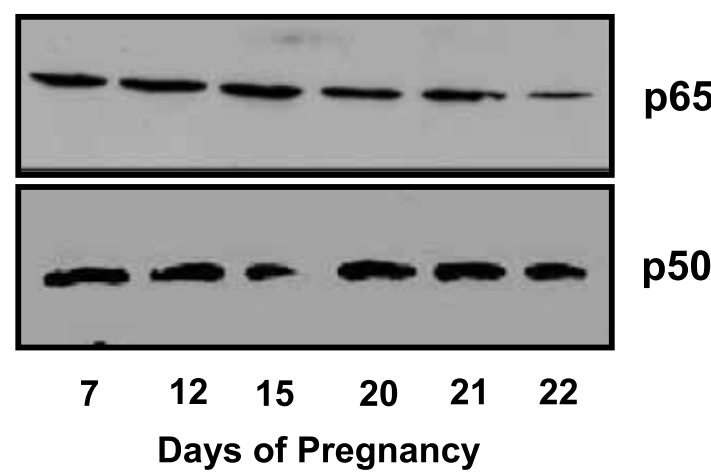

Figure 1 Tissue specificity and changes in NFKB/p65 and p50 immunoreactive proteins in the rat corpus luteum during pregnancy. (A) Corpora lutea (CL) were obtained from rats on day 15 of pregnancy, and prostate $(P)$, epididymis $(E)$, and spleen $(S)$ were isolated from adult males. (B) Corpora lutea were obtained from rats killed on days $7,12,15,20,21$, and 22 of pregnancy. Total protein extract was obtained from the different tissues and equal amounts of proteins $(50 \mu \mathrm{g})$ were separated by SDS-PAGE, transferred to nitrocellulose, and analyzed by Western blot as described in Materials and methods. Depicted are autoradiographs from a representative experiment.

found by Western blot throughout pregnancy (Fig. $3 \mathrm{~A})$. Phosphorylation of $\mathrm{I} \kappa \mathrm{B} \alpha$ indicates that most probably translocation of $\mathrm{NF \kappa B}$ to the nucleus is continuously taking place in the corpus luteum during pregnancy, opening the possibility for a physiological role of the transcription factor in the regulation of luteal function. To demonstrate this possibility further, we studied the capacity of nuclear luteal extracts to bind an NFKB DNA consensus sequence. Nuclear extracts obtained from corpora lutea of day 5 pregnant rats were 

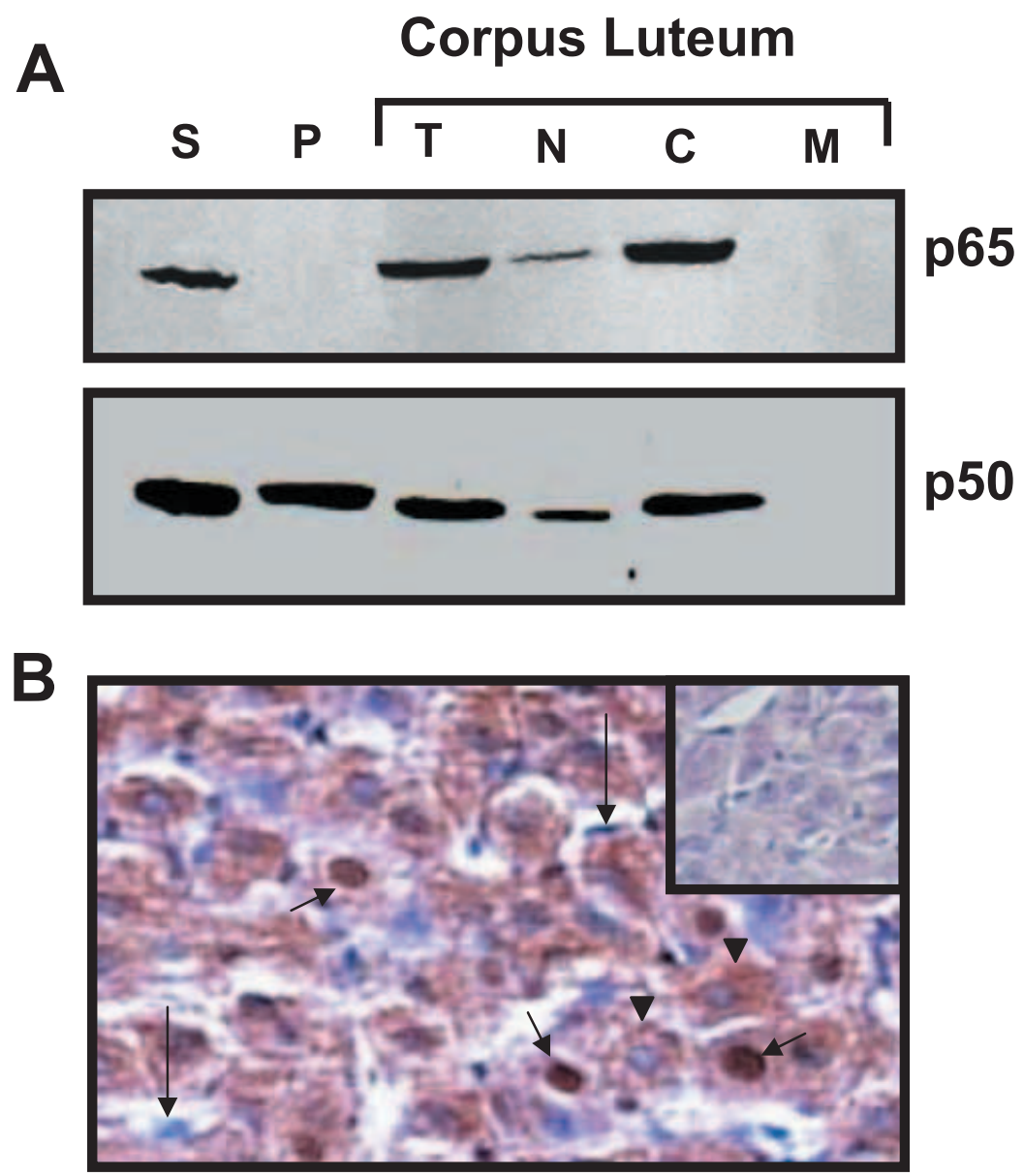

Figure 2 Cellular localization of $\mathrm{NF} / \mathrm{B} / \mathrm{p} 65$ and p50 proteins in the rat corpus luteum. (A) Corpora lutea were isolated from rats on day 15 of pregnancy: $\mathrm{T}$, total extract; $\mathrm{N}$, nuclear extract; $\mathrm{C}$, cytosolic extract; $\mathrm{M}$, membrane extract. Total extracts from spleen $(S)$ and prostate $(P)$, were used as positive and negative control respectively for NFKB/p65 according to the results obtained and shown in Fig. 1. Western blot was conducted as detailed in Fig. 1 and in Materials and methods. (B) Ovaries were obtained from rats on day 15 of pregnancy and analyzed by immunohistochemistry for the presence of NFKB/p65 as detailed in Materials and methods. NFkB/p65 depicts nuclear (short arrows) as well as cytoplasmic (arrowheads) localization in luteal cells, whereas no staining is observed in the endothelial cells surrounding the capillaries (long arrows). The inset depicts absence of immunostaining in luteal cells when the ovarian section was incubated with TBS instead of $\mathrm{NF} \kappa \mathrm{B} / \mathrm{p} 65$ antibody. Magnification $\times 400$.

capable of binding an NFKB DNA consensus sequence, as demonstrated by either protein/DNA array (Fig. 3B) or EMSA (Fig. 3C). To explore the specificity of the binding of nuclear luteal proteins to the NFкB probe, we performed gel shift analysis with specific antibodies for the different subunits capable of forming the NFкB complex (Siebenlist et al. 1994, Mercurio \& Manning 2000). As shown in Fig. 4, we found a strong shift of the NFкB probe induced by the nuclear extract. This binding was specific as demonstrated by their competition with excess cold probe, and by the fact that the binding was not competed by a mutant probe. The nature of the proteins bound to the NFkB probe was revealed by using specific antibodies for the known components of the NFKB family of proteins. 


\section{A}

Days of Pregnancy
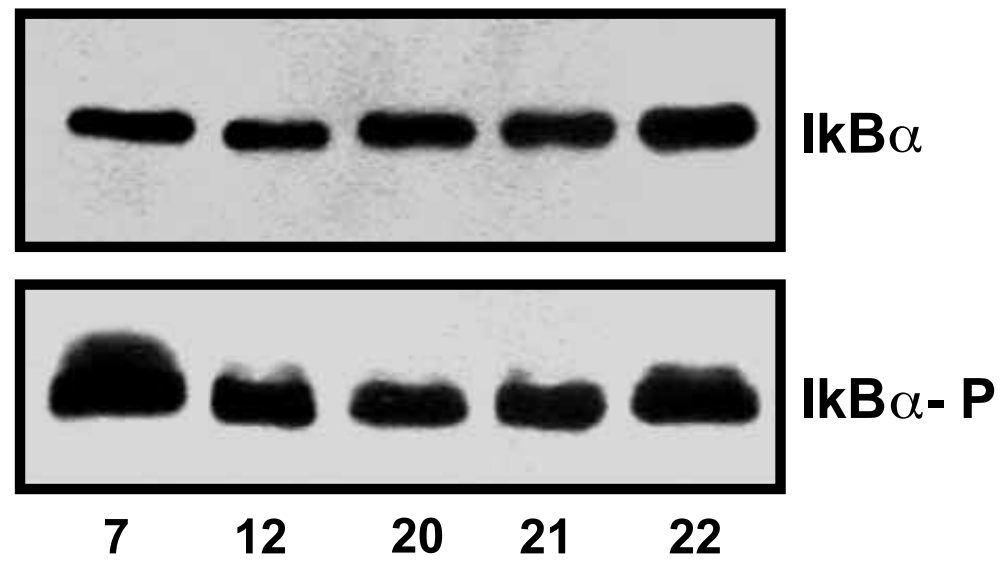

B

\section{Protein / DNA Array}
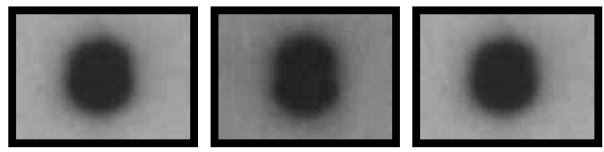

C

\section{EMSA}

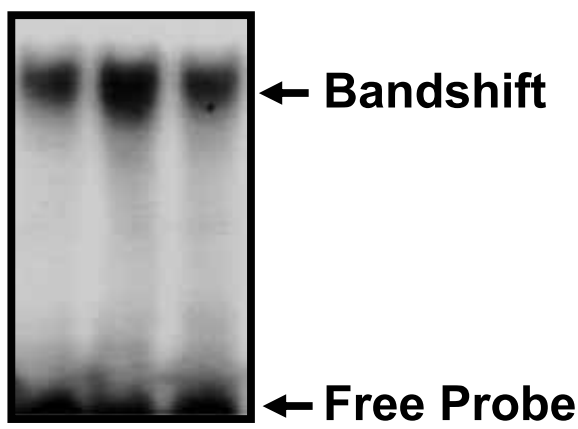

Figure 3 Expression of $I \kappa B \alpha$ in the rat corpus luteum during pregnancy and binding of luteal nuclear extracts to an NFKB DNA consensus sequence. (A) Corpora lutea were obtained from rats killed on days $7,12,15,20,21$, and 22 of pregnancy. Cytosolic extracts were obtained from the corpora lutea and equal amounts of proteins $(50 \mu \mathrm{g})$ were separated by SDS-PAGE, transferred to nitrocellulose, and analyzed by Western blot as described in Materials and methods. Depicted are autoradiographs from representative experiments. (B) Binding of nuclear extracts obtained from corpora lutea of three rats on day 5 of pregnancy and subjected to protein/DNA array as described in Materials and methods. (C) Binding to an NFKB DNA consensus sequence of the same nuclear extracts analyzed in (B) and evaluated by EMSA. 


\section{Corpus Luteum}

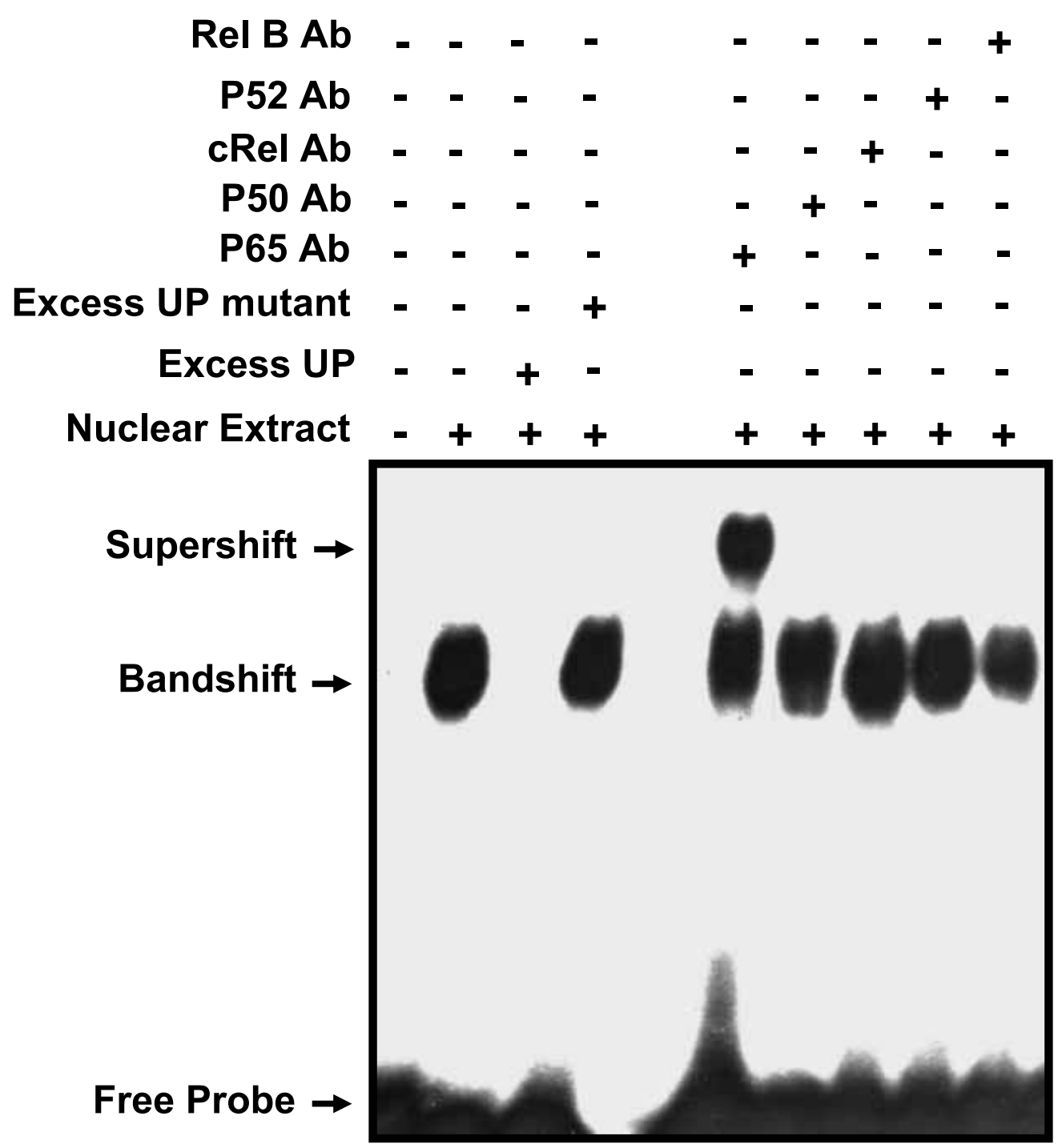

Figure 4 Identification of NFKB complexes in the corpus luteum. EMSA was performed using a probe containing the sequence of a classical NFKB binding site (Rel) and equal amounts of nuclear extracts in the presence and absence of antibodies (Ab), a 100-fold excess of unlabeled NFKB probe (UP) or 100 -fold excess of unlabeled NFKB mutant probe as indicated at the upper left margin of the figure. Arrows in the left margin mark the positions of the NFKB-specific complexes. A supershifted complex is also indicated. DNA/protein complexes were resolved by nondenaturing PAGE and detected by autoradiography. The unbound probe is shown at the bottom of the gel (free probe). The experiment depicted was performed in triplicate with consistent results.

The specific binding was supershifted by only the antibody directed against the NFKB/p65 protein. No supershift whatsoever was seen when antibodies directed against p50, cRel, p52, or RelB were used.
This result indicates that p65 is the major NFкB component within the corpus luteum. Analogous information was obtained when nuclear extracts were isolated from the luteal cell line GG-CL 


\section{GG-CL Cells}
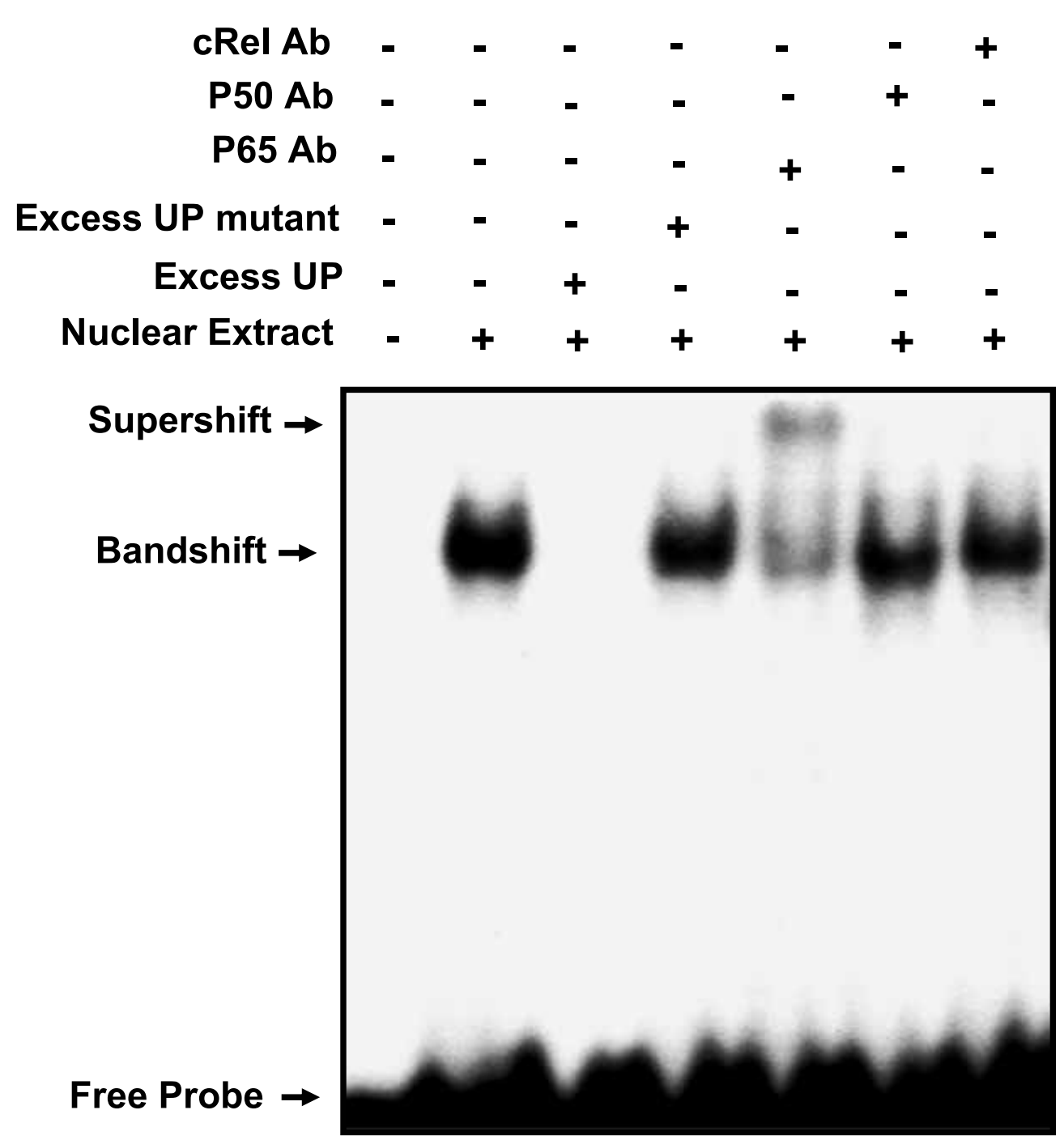

Figure 5 Identification of NFKB complexes in the GG-CL luteal cell line. EMSA was performed using a probe containing the sequence of a classical NFKB binding site (Rel) and equal amounts of nuclear extracts in the presence and absence of antibodies (Ab), $a$ 100 -fold excess of unlabeled NFKB probe (UP) or 100-fold excess of unlabeled NFKB mutant probe as indicated at the upper left margin of the figure. Arrows in the left margin mark the positions of the NFKB-specific complexes. A supershifted complex is also indicated. DNA/protein complexes were resolved by nondenaturing PAGE and detected by autoradiography. The unbound probe is shown at the bottom of the gel (free probe). The experiment depicted was performed in triplicate with consistent results.

(Fig. 5). Similarly to what was observed in the corpus luteum, in GG-CL cells p65 was the only component of the NFKB family of proteins capable of binding the $\mathrm{NF \kappa B}$ consensus sequence.
This was demonstrated by the supershifted band obtained when the protein extract and the probe were incubated in the presence of the anti-p65 antibody. 


\section{C}

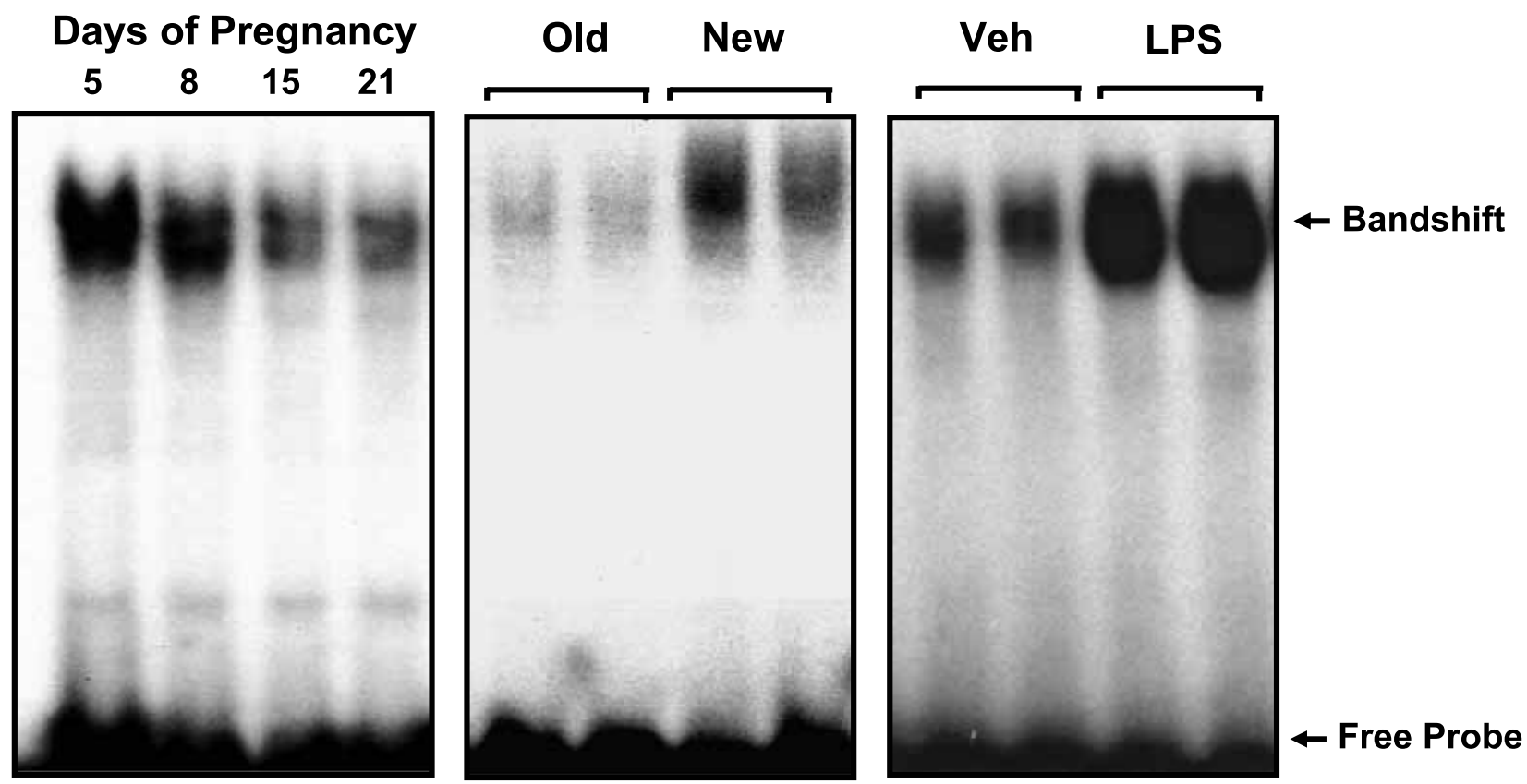

Figure 6 Developmental regulation of $\mathrm{NF}_{\kappa} \mathrm{B}$ binding to an NFKB consensus sequence in the corpus luteum of pregnancy. EMSA was performed using a probe containing the sequence of a Rel binding site and equal amounts of nuclear extracts. (A) Nuclear extracts were obtained from corpora lutea of rats killed on days 5, 8, 15, and 21 of pregnancy; (B) nuclear extracts were from old corpora lutea of pregnancy (Old) or newly formed corpora lutea after postpartum ovulation (New), which were isolated from rats killed on day 4 postpartum; (C) nuclear extracts were isolated from rats killed on day 15 of pregnancy that were treated with either saline vehicle (Veh) or LPS (5 mg i.p.) $2 \mathrm{~h}$ before being killed. The arrow in the right margin marks the position of the NFkB-specific complexes. The unbound probe is shown at the bottom of the gel (free probe). Experiments shown were performed in triplicate with consistent results.

\section{Binding of NFKB to an NFKB consensus sequence is developmentally regulated in pregnancy, varies with the age of the corpus luteum, and can be further activated by LPS and PRL}

Once we had established that p65 is the major member of the NFKB family of proteins binding DNA in the corpus luteum, we decided to determine whether such binding is developmentally regulated in pregnancy, and whether it is affected by the ubiquitous NFKB stimulator LPS (Manna \& Aggarwal 1999), and the luteal regulatory hormone PRL (Risk \& Gibori 2001). The binding of nuclear proteins obtained from corpora lutea of different days of pregnancy decreased while gestation advanced, demonstrating that the activation of this transcription factor is developmentally regulated in pregnancy (Fig. 6A). The binding appeared to be age-dependent if comparing the weak binding elicited by nuclear proteins obtained from the old corpus luteum of pregnancy harvested on day 4 postpartum, with the stronger binding elicited by nuclear extracts obtained from newly formed corpora lutea after postpartum ovulation and harvested on day 4 postpartum as well (Fig. 6B). Nuclear extracts obtained from corpora lutea of day 15 of pregnancy, which showed lower binding to DNA as compared with that of days 5 and 8 of pregnancy (Fig. 6A), had a remarkably increased binding to the NFKB consensus sequence after in vivo challenge with LPS (Fig. 6G).

In order to study the regulation of $\mathrm{NF \kappa B}$ activation by PRL in ovarian cells, we took advantage of an in vitro approach. We used primary luteinized granulosa cells in culture which respond to PRL with increased production of progesterone (Jones et al. 1983, Risk \& Gibori 2001). As shown in Fig. 7, cellular extracts from these cells bind 
A

\section{Luteinized Granulosa Cells}

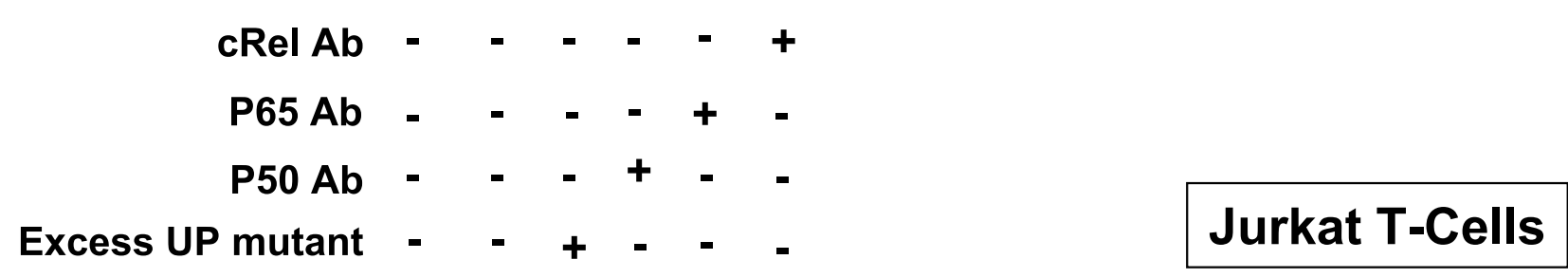

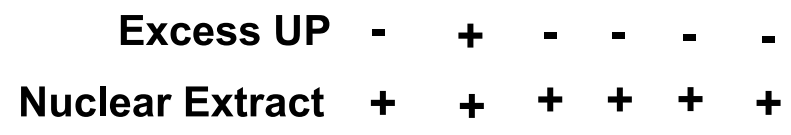

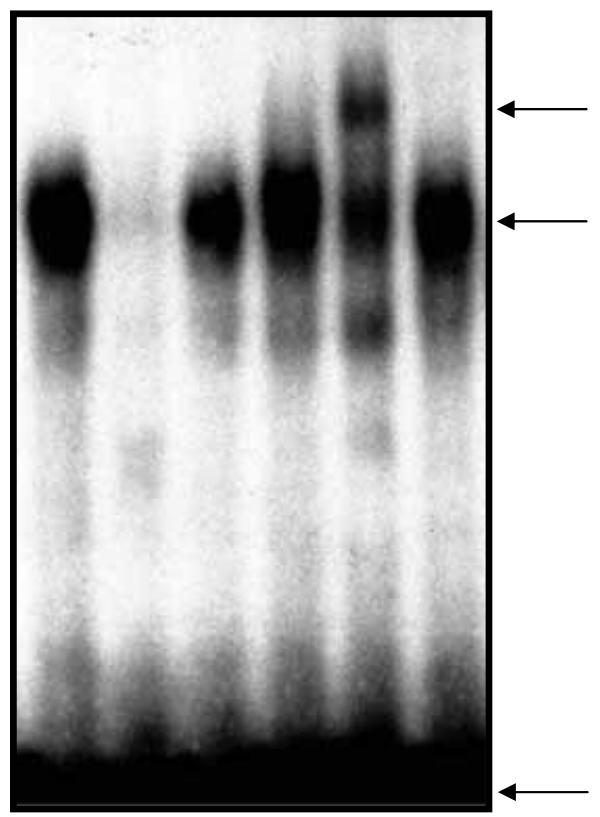

\section{Jurkat T-Cells}

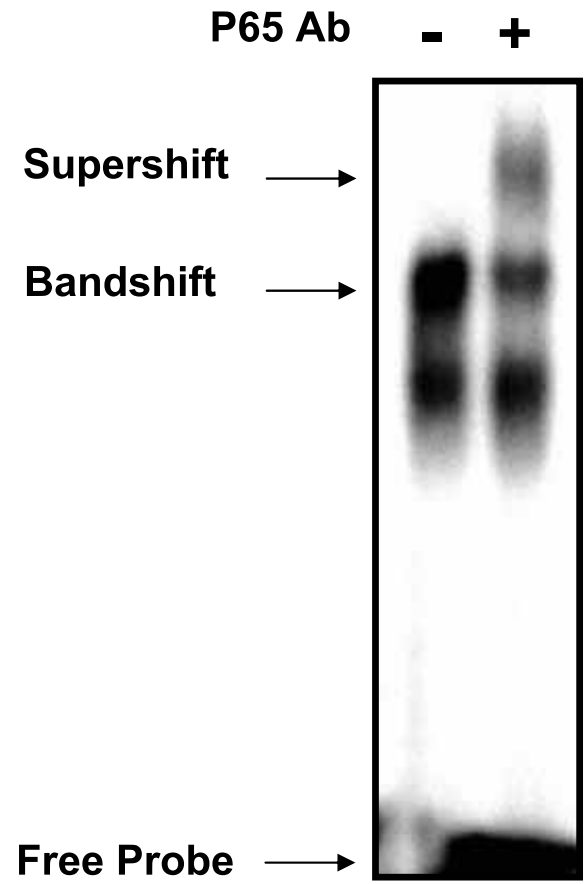

Figure 7 Identification of $\mathrm{NF} \kappa \mathrm{B}$ complexes in primary luteinized granulosa cells. (A) EMSA was performed using a probe containing the sequence of a classical NFKB binding site (Rel) and equal amounts of nuclear extracts in the presence and absence of antibodies (Ab), a 100-fold excess of unlabeled NFKB probe (UP) or 100-fold excess of unlabeled $N_{F} B$ mutant probe as indicated at the upper left margin of the figure. Arrows in the right margin mark the positions of the NFKB-specific complexes. A supershifted complex is also indicated. DNA/protein complexes were resolved by nondenaturing PAGE and detected by autoradiography. The unbound probe is shown at the bottom of the gel (free probe). The experiment shown was performed in triplicate with consistent results. (B) Binding of nuclear extract from TPA-treated Jurkat T-cells and the Rel consensus DNA sequence. Note that the supershifted band by the anti-p65 antibody observed in Jurkat T-cells migrates similarly to that in luteinized granulosa cells.

specifically to the $\mathrm{NF \kappa B}$ binding site since this binding was competed by a cold but not by a mutated NFKB probe. Similarly to what we observed in the corpus luteum, p65 was the only component of the $\mathrm{NF \kappa B}$ family of proteins recognized in the protein/DNA complex in luteinized granulosa cells (Fig. 7A). Nuclear extracts obtained from Jurkat T-cells treated with TPA and calcium ionophore were run in parallel and showed similar bands to those obtained in ovarian cells. The band supershifted in the presence of the anti-p65 antibody was similar in both cell types 


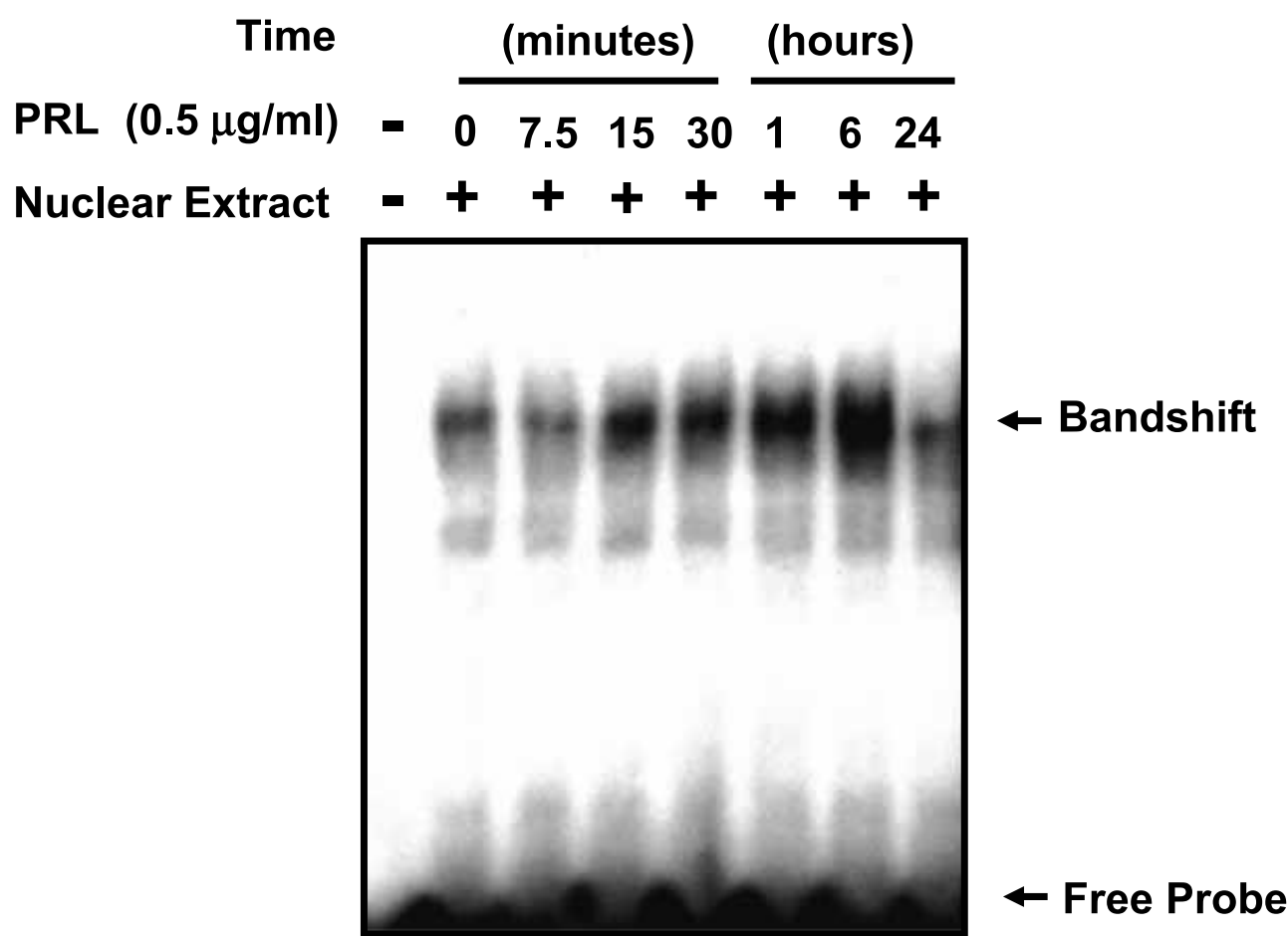

Figure 8 Nuclear extracts from luteinized granulosa cells treated with PRL have a time-dependent increase in binding to a Rel consensus sequence. Primary luteinized granulosa cells were treated with $0.5 \mu \mathrm{g} / \mathrm{ml}$ oPRL for the times depicted. DNA/protein complexes were resolved by nondenaturing PAGE and detected by autoradiography. The unbound probe is shown at the bottom of the gel (free probe). Experiment shown was performed in triplicate with consistent results.

(Fig. 7A and B). When luteinized granulosa cells were treated with PRL for various times (Fig. 8), an increase in $\mathrm{NF \kappa B}$ binding activity was observed within $15 \mathrm{~min}$ and remained elevated for $6 \mathrm{~h}$. A decrease in binding activity was observed after $24 \mathrm{~h}$.

\section{Blocking NFкB/p65 binding to an NFкB response element correlates with cell death in luteinized granulosa cells}

In order to determine a role for $\mathrm{NF \kappa B}$ in luteal function, we took advantage of the previous observation that p65 is the main component of NFkB able to bind DNA in luteal as well as luteinized granulosa cells. We cultured primary luteinized granulosa cells in the presence of helenalin, a sesquiterpene lactone that inhibits $\mathrm{NF} \kappa \mathrm{B}$ by specific and irreversible alkylation of the p65 subunit, thereby blocking DNA binding (Lyss et al. 1998). To confirm that helenanin blocked binding of $\mathrm{NF \kappa B}$ to DNA we performed a time-course experiment in luteinized granulosa cells in the presence of different doses of the compound. As expected, helenalin was capable of blocking binding of nuclear extracts to the NFkB probe within $1 \mathrm{~h}$ of treatment, whereas the inhibition persisted for at least $6 \mathrm{~h}$ (Fig. 9). After confirming that helenalin blocked binding of $\mathrm{NF} \kappa \mathrm{B} / \mathrm{p} 65$ to DNA, we examined whether inhibition of $\mathrm{NF \kappa B}$ activity causes ovarian cell death as previously reported for other cell types (Yamamoto \& Gaynor 2001, Orlowski \& Baldwin 2002). The results shown in Fig. 10 indicate that helenalin was capable of inducing ovarian cell death in a dose-dependent manner. Observations on the morphology of the cells in a bright field indicate that the ovarian cells in culture most probably undergo cell death in the presence of helenalin, and the condensation of the chromatin after DAPI staining clearly confirms such a previous presumption. 


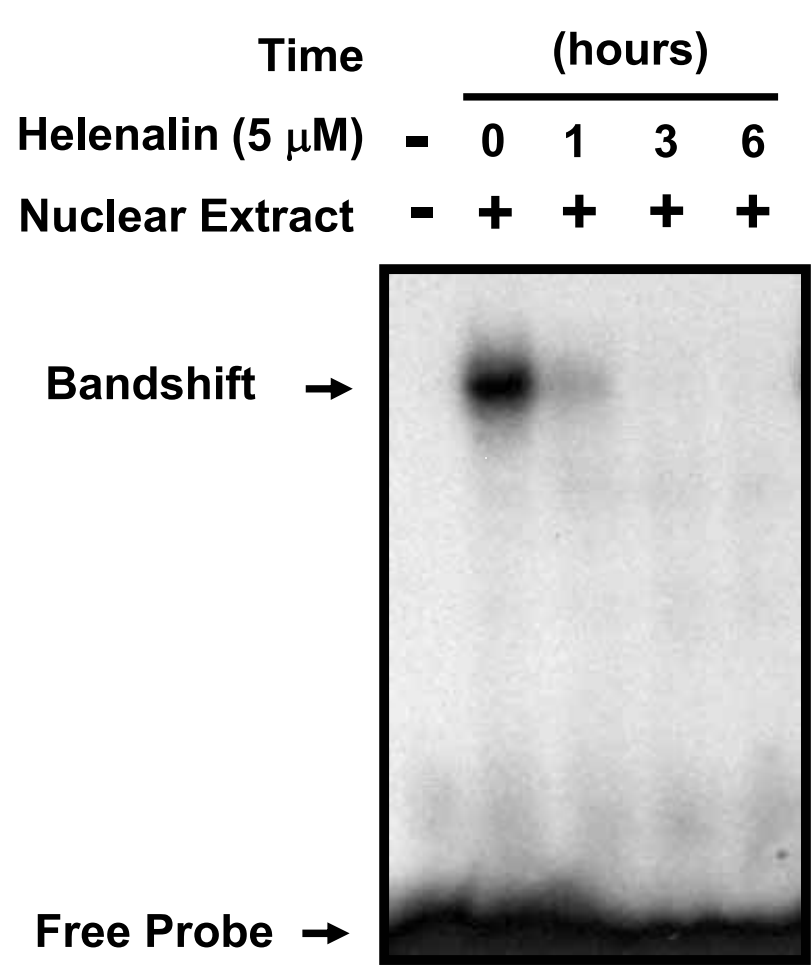

Figure 9 Time-course inhibition of binding of nuclear extracts of luteinized granulosa cells by treatment with helenalin. Nuclear extracts from luteinized granulosa cells treated with either helenalin or vehicle were analyzed by EMSA using a probe containing the Rel response element. Experiments were repeated three times, and results from one representative experiment are shown.

\section{Overexpression of NFkB/p65 in GG-CL luteal cells inhibits the expression of the $20 \alpha \mathrm{HSD}$ gene}

Previous data from our laboratory indicated that the potent NFKB activator LPS decreased the expression of the progesterone-catabolizing enzyme $20 \alpha$ HSD in rat luteinized granulosa cells (Telleria et al. 2000). In addition, our laboratory has previously cloned the cDNA encoding 20aHSD (Mao et al. 1994). This gene is highly induced before parturition when luteal regression is taking place, and its induction is crucial in order for parturition to occur (Wiest et al. 1968). We have

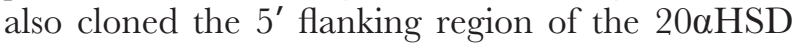
gene (Zhong et al. 1998), which revealed the presence of three putative NFKB response elements at positions $-2393,-1484$, and -222 from the transcription starting site. The sequence of the $\mathrm{NF \kappa B}$ response element located between pos- itions -222 and -213 contains a perfect Rel sequence known to bind NFkB/p65 (GGGGTAT TCG). In order to determine the possible role of NFKB as regulator of $20 \alpha \mathrm{HSD}$ gene expression, we transfected GG-CL luteal cells with the full-length $2.5 \mathrm{~kb} 20 \alpha \mathrm{HSD}$ promoter linked to a luciferase reporter gene, and incubated the cells in the presence of increasing concentrations of an $\mathrm{NF \kappa B} / \mathrm{p} 65$ expression plasmid. We found that transfection of the $\mathrm{NF \kappa B} / \mathrm{p} 65$ expression plasmid induced a decrease in the activity of the $20 \alpha \mathrm{HSD}$ promoter in a DNA-dependent fashion (Fig. 11A) together with a decrease in the endogenous levels of mRNA encoding 20aHSD (Fig. 11B and G).

\section{Discussion}

The corpus luteum is a transient endocrine gland whose life span is limited to accomplish a specific reproductive function. While functioning, the cells composing the corpus luteum appear to be terminally differentiated and committed to the production of progesterone. When progesterone is no longer needed the corpus luteum regresses through a process that involves loss of progesterone-producing capacity and cell death. To achieve its mission luteal cells are subjected to a fine-tuned regulation by hormones. In the pregnant rat, the corpus luteum is maintained in function by PRL, placental lactogens, luteinizing hormone, progesterone, androgens and estrogens (Risk \& Gibori 2001). In the present study, we introduced the transcription factor $\mathrm{NF \kappa B}$ as a putative mediator of hormonally controlled mechanisms involved in luteal cell function and survival. The fact that NFKB activation in the corpus luteum was developmentally regulated in pregnancy suggests that such activation is under hormonal control. This reasoning is supported by the results showing that the basal activation status of NFKB in cultured luteinized cells was increased by the presence of PRL. These results also suggest that PRL may control the expression of certain luteal genes by regulating $\mathrm{NF \kappa B}$ activation. In this regard, we have demonstrated that $\mathrm{NF \kappa B}$ is capable of silencing the expression of the 20aHSD gene, which has been shown to be inhibited by PRL in the corpus luteum (Albarracin et al. 1994, Zhong et al. 1997); however, whether PRL inhibition of $20 \alpha \mathrm{HSD}$ in luteal cells involves $\mathrm{NF \kappa B}$ activation requires further 


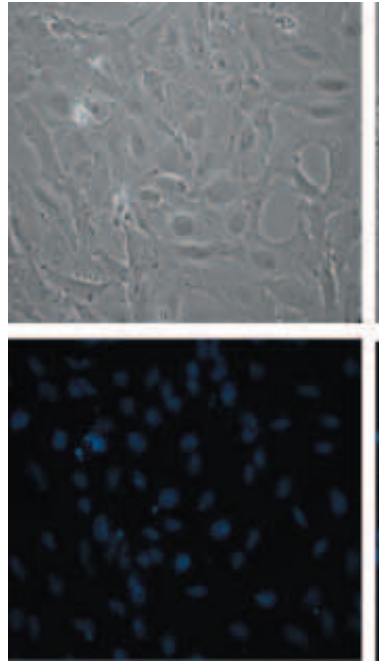

Vehicle
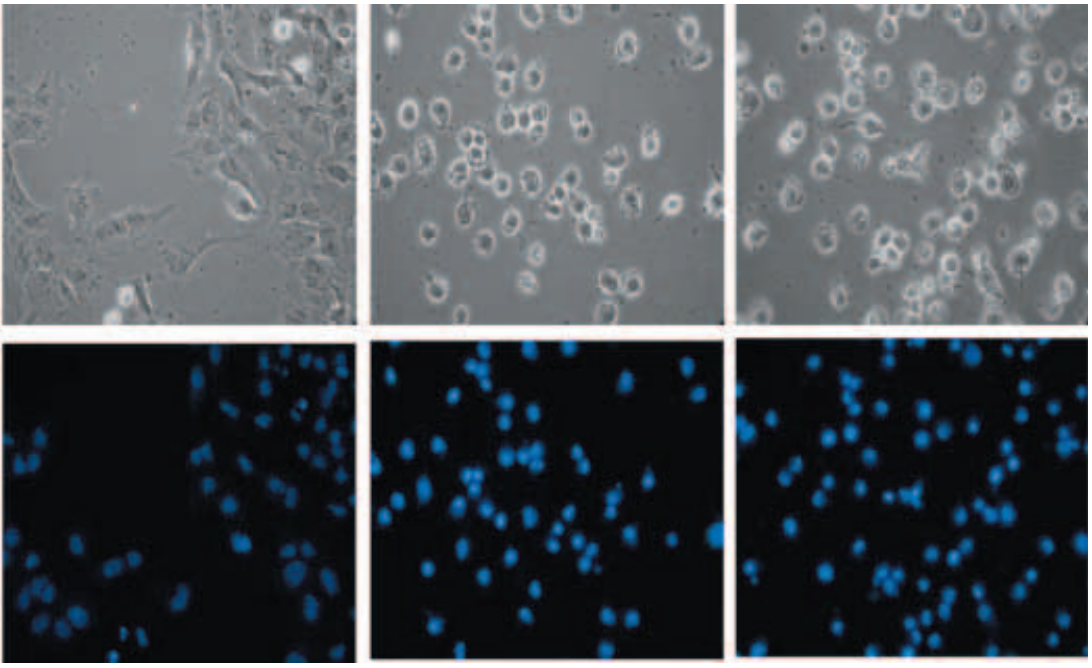

He $1 \mu \mathrm{M}$

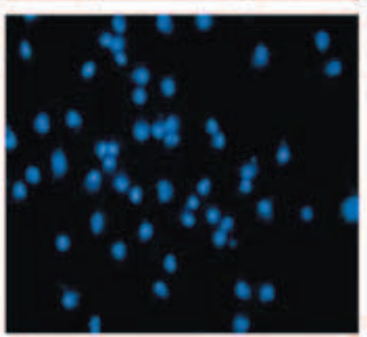

He $5 \mu \mathrm{M}$

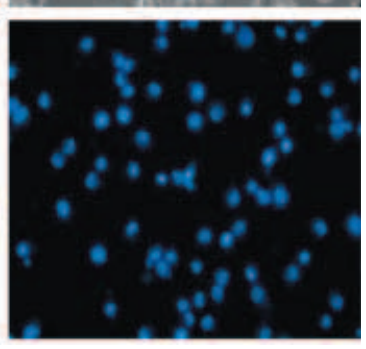

He $10 \mu \mathrm{M}$

Bright Field

\section{DAPI}

Figure 10 Culture of primary luteinized granulosa cells in the presence of different concentrations of the p65 inhibitor helenalin. The cells were treated with vehicle or 1,5 , or $10 \mu \mathrm{M}$ helenalin for $6 \mathrm{~h}$. At the end of the incubation, the cells were fixed and stained with DAPI. Images were taken in parallel in bright fields (top panels) and fluorescence fields (DAPI; bottom panels). Magnification $\times 200$.

investigation. In addition, we have shown that by inactivating $\mathrm{NF \kappa B}$, cell death can be induced in luteinized cells, opening the possibility for a role of $\mathrm{NF} \kappa \mathrm{B}$ in controlling the expression of genes involved in cell survival and apoptosis.

The p50 and p65 proteins are essentially present in all cells (Siebenlist et al. 1994) and this was also true for luteal cells. In the corpus luteum we showed that both p50 and p65 proteins are expressed in the cytoplasm and nucleus of the luteal cells. Even though the p50/p65 dimer is the most frequent $\mathrm{NF \kappa B}$ complex in different cell types, including reproductive organs such as testis (Delfino \& Walker 1998) and mammary gland (Geymayer \& Doppler 2000), our results indicate that p65 is the major member of the NFkB family of proteins capable of binding DNA in the corpus luteum, most probably as a p65/p65 homodimer. Even if p50 does not bind DNA associated with $\mathrm{p} 65$, it may have a role in luteal function by forming complexes with other members of the $\mathrm{NF \kappa B}$ family of proteins, and regulating gene expression by binding other response elements distinct from the classical NFKB DNA element (Rel) tested in our study. Therefore the function of p50 in luteal cells needs further investigation. It is also interesting to note from our immunohistochemistry studies that the presence of p65 within luteal cells varied from cell to cell. Whereas p65 in some cells showed strong nuclear localization, it was less abundant in other surrounding cells. Additionally, the abundance of p65 in the cytoplasm also varied between cells. This may indicate that the activation status of $\mathrm{NF} \kappa \mathrm{B}$ in luteal cells is not synchronized along the entire gland and that in each particular luteal cell the transcription factor might be regulating physiological processes in need of being controlled on a cell-to-cell basis. The absence of p52, cRel and RelB within the protein/DNA complexes in the corpus luteum was not surprising since the expression of these NFKB subunits is mainly restricted to hematopoietic organs (Beauparlant \& Hiscott 1996).

Despite p65 appearing to be constitutively expressed in the corpus luteum throughout pregnancy, its activation status (i.e. its capacity to bind an NFkB DNA consensus sequence) varied along pregnancy. It is clear that the binding capacity of p65 to DNA decreased while pregnancy advanced, suggesting that NFKB activation depends on the age of the corpus luteum. This was confirmed by the abundant binding to the DNA probe of nuclear extracts obtained from young corpora lutea as compared with nuclear extracts obtained from old corpora lutea of pregnancy, both coexisting in the same ovaries of rats 4 days after 
parturition. As we demonstrated that p65 binding to DNA is important for cell survival and for inhibition of $20 \alpha \mathrm{HSD}$, it is tempting to speculate that early on in pregnancy young corpora lutea having $\mathrm{NF \kappa B}$ highly activated are better protected against insults that threaten normal luteal function; one such insult could be the activation of 20aHSD gene expression, which leads to increased progesterone catabolism, luteal regression, and termination of pregnancy (Wiest et al. 1968).

The decline in NFKB DNA binding at the end of pregnancy in the rat corpus luteum does not appear to be due to a decline in $\mathrm{p} 65$ protein expression and/or to I $\mathrm{B}$ phosphorylation. Whether it involves protein-protein interaction

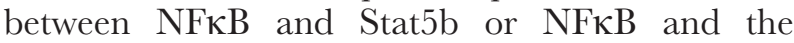
glucocorticoid receptor, as previously shown for other cell types (May \& Ghosh 1998, Luo \& Yu-Lee 2000), remains to be investigated. The loss of sensitivity of the corpus luteum to PRL at the time of luteal regression may contribute to the low activation status of $\mathrm{NF \kappa B}$ found at the end of pregnancy in our studies. At the end of pregnancy in the rat, PRL does no longer target the corpus luteum. This is first due to the lack of sensitivity caused by the rapid expression of inhibitor of cytokine signaling molecules that interfere with PRL signaling (Curlewis et al. 2002), and second, because of the disappearance of PRL receptors (Telleria et al. 1997), most probably due to luteolytic signals triggered by prostaglandin F2 $\alpha$ (Stocco et al. 2003). The fact that PRL was capable of stimulating NFKB in luteinized cells is consistent with the tropic action of PRL through most of pregnancy, which may well be stimulating NFкB. The decrease in NFKB binding activity at the end of pregnancy (day 21) coincides with the disappearance of PRL receptors (Telleria et al. 1997). Thus, because PRL can no longer target the corpus luteum at the end of pregnancy, this may lead to a decrease in NFKB activity. In addition, because

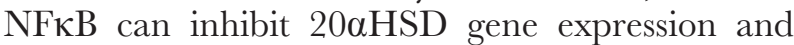
protect against apoptosis, the abrupt decrease in $\mathrm{NF} \kappa \mathrm{B}$ binding activity observed at the end of pregnancy may be permissive to apoptogenic and antisteroidogenic signals favoring luteal regression. Whereas 20aHSD gene is repressed by PRL, it is upregulated by prostaglandin F2 $\alpha$ through the induction of transcription factor NUR77 (Stocco et al. 2000). The involvement of $\mathrm{NF \kappa B}$ in the regulation of $20 \alpha \mathrm{HSD}$ may indirectly affect the intraluteal levels of prostaglandin $\mathrm{F} 2 \alpha$. The rabbit 20 $\alpha$ HSD has prostaglandin E2 9-ketoreductase activity (Wintergalen et al. 1995) and may convert intraluteal prostaglandin E2 to prostaglandin F2 $\alpha$. Thus, lack of inhibition of $20 \alpha \mathrm{HSD}$ during luteal regression by $\mathrm{NF} \kappa \mathrm{B}$ may lead, if the rat enzyme expresses the 9-ketoreductase activity, to conversion of prostaglandin E2 (potentially luteotropic and antiapoptotic) to prostaglandin F2 $\alpha$ (luteolytic and proapoptotic), which may further stimulate the expression of $20 \alpha \mathrm{HSD}$.

It has been shown in hormonally sensitive cancer cells, such as prostate cancer cells, that androgeninduced resistance to apoptotic stimuli (e.g. radiation-induced apoptosis) involves activation of NFкB (Coffey et al. 2002). This protection was eliminated when prostate cancer cells overexpressed an I $\mathrm{KB}$ superrepressor, suggesting that activation of $\mathrm{NF \kappa B}$ is required in the androgen survival signaling. Similarly in the corpus luteum of pregnancy we may assume that PRL, which is a survival factor according to recent evidence presented from our as well as another laboratory (Goyeneche et al. 2003b, Kawaminami et al. 2003), may elicit its effect by activating NFKB.

Our results also show that the binding of NFKB to DNA at mid-pregnancy could be further activated by the inflammatory endotoxin LPS. The induction of NFKB by LPS could mediate a survival or antiapoptotic signaling pathway in luteal cells. This speculation is based on the fact that by activating NFKB, LPS was capable of inducing resistance to apoptosis triggered by TNF- $\alpha$, Taxol (a microtubule-binding diterpene), and okadaic acid (an inhibitor of serine/threonine protein phosphatase) in tumor cell lines (Manna \& Aggarwal 1999). Our results showing that NFאB is

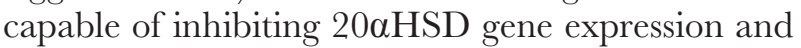
that LPS stimulates NFKB DNA binding are also consistent with our previous studies showing LPS-induced inhibition of 20aHSD mRNA expression in luteinized granulosa cells (Telleria et al. 2000). By stimulating NFkB, LPS may have a

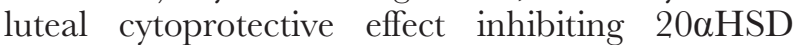
expression and opposing apoptosis. On the other hand, LPS has been shown to induce expression of inflammatory cytokines and prostaglandins in the pregnant rat uterus leading to preterm birth (Bennett et al. 2000). Thus, upon systemic LPS infusion, an initial LPS-induced cytoprotective effect in the corpus luteum mediated through 


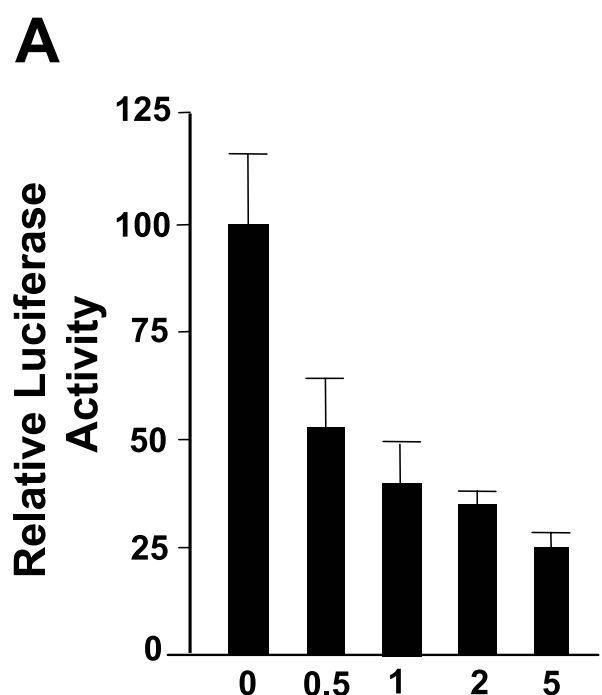

$\mu \mathrm{g}$ plasmid DNA / well
B

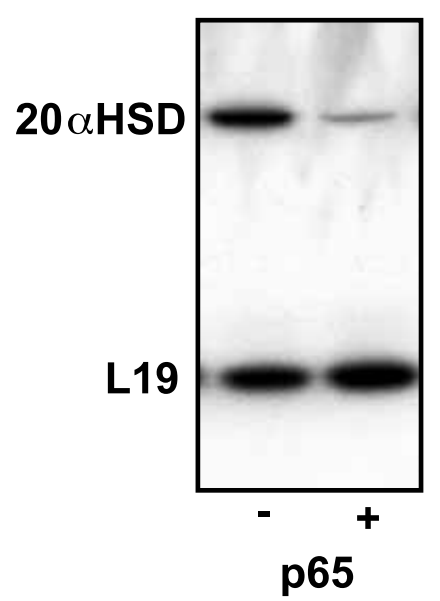

C

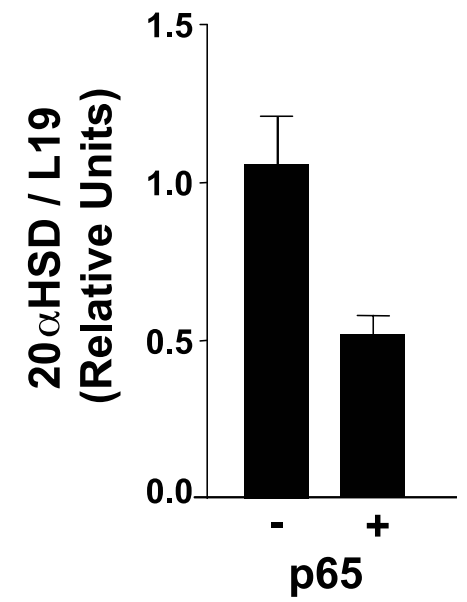

Figure $11 \mathrm{NF \kappa B} / \mathrm{p} 65$ inhibits $20 \alpha \mathrm{HSD}$ gene expression. (A) Luteal cells were co-transfected with $1 \mu \mathrm{g} / \mathrm{well}$ of the $20 \alpha \mathrm{HSD}$-Luc promoter, $3 \mu \mathrm{g} / \mathrm{well}$ of a control $\beta$-galactosidase expression vector, and $0.5,1,2$, or $5 \mu \mathrm{g} / \mathrm{well}$ of an $\mathrm{NF \kappa B} / \mathrm{p} 65$ expression vector. Relative light units were obtained by dividing the luciferase activity by the $\beta$-galactosidase activity. (B and C) Endogenous 20aHSD mRNA levels in luteal cells transfected with none (-), or $5 \mu \mathrm{g} /$ well of the NFKB/p65 expression vector. 20 $\mathrm{HSSD}$ mRNA was measured using semiquantitative RT-PCR.

Experiments were repeated three times; results from a representative set are shown. Bars represent means \pm S.E.M. $(n=3)$.

$\mathrm{NF} \kappa \mathrm{B}$ activation may be overridden by induction of prostaglandin production in the uterus, leading to uterine contraction, preterm delivery, and secondary luteal regression.

Another target gene whose expression has been shown to be regulated by $\mathrm{NF \kappa B}$ is that for manganese superoxide dismutase (Mn-SOD) Jones et al. 1997). The enzyme encoded by this gene is expressed in the rat corpus luteum of pregnancy and protects the gland against toxic oxygen radicals by scavenging superoxide radicals (Sugino et al. 1993). We have previously shown that LPS stimulated Mn-SOD expression in pregnant rat corpora lutea within $2 \mathrm{~h}$ of treatment (Sugino et al. $1998 b$ ), which coincides with the induction of $\mathrm{NF} \kappa \mathrm{B} / \mathrm{DNA}$ binding induced by the endotoxin in our present study. Further studies will be needed, however, to determine whether $\mathrm{NF} \kappa \mathrm{B}$ regulates Mn-SOD gene expression in the rat corpus luteum.

To the best of our knowledge, this is the first report showing that blockage of NFkB/p65 binding to DNA in luteinized granulosa cells correlates with induction of cell death. Primary granulosa cells obtained from rats do not die if subjected to serum deprivation (G M Telleria, A A Goyeneche, C O Stocco and G Gibori, unpublished observations) or to proapoptogenic compounds such as TNF- $\alpha$ (Xiao et al. 2001) or Fas ligand (Quirk et al. 1998) alone. Only if combined with the protein synthesis inhibitor cycloheximide, were TNF- $\alpha$ (Xiao et al. 2001) and Fas ligand (Quirk et al. 1998) capable of triggering granulosa cell death. TNF- $\alpha$ in these cells stimulated expression of inhibitor of apoptosis proteins (IAPs) through an NFkB-dependent process (Xiao et al. 2001, 2002). Therefore, it is reasonable to speculate that $\mathrm{NF \kappa B}$ could play a central role in the prevention of cell death in the corpus luteum by stimulating the expression of IAPs, such as Xiap (Xiao et al. 2001) and/or FLIP (Xiao et al. 2002).

\section{Acknowledgements}

This research was supported by NIH grants HD 11119, FIRCA 1R03 TW01049-03, and NGRR 5 P20 RR16479-02. We are grateful to Dr J Anrather for the RelA expression vector.

\section{References}

Albarracin CT, Parmer TG, Duan WR, Nelson SE \& Gibori G 1994 Identification of a major prolactin-regulated protein as 
$20 \alpha$-hydroxysteroid dehydrogenase: coordinate regulation of its activity, protein content, and messenger ribonucleic acid expression. Endocrinology 134 2453-2460.

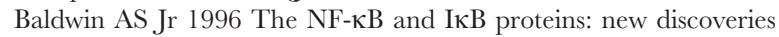
and insights. Annual Review of Immunology 14 649-681.

Beauparlant P \& Hiscott J 1996 Biological and biochemical inhibitors of the NF- $\mathrm{kB} /$ Rel proteins and cytokine synthesis. Cytokine and Growth Factor Reviews 7 175-190.

Bennett WA, Terrone DA, Rinehart BK, Kassab S, Martin JN Jr \& Granger JP 2000 Intrauterine endotoxin infusion in rat pregnancy induces preterm delivery and increases placental prostaglandin F2 alpha metabolite levels. American Fournal of Obstetrics and Gynecology 182 1496-1501.

Blackwell TS \& Christman JW 1997 The role of nuclear factor-kB in cytokine gene regulation. American Fournal of Respiratory Cell and Molecular Biology 17 3-9.

Brenner RM, Nayak NR, Slayden OD, Critchley HOD \& Kelly RW 2002 Premenstrual and menstrual changes in the macaque and human endometrium. Relevance to endometriosis. Annals of the New York Academy of Sciences 955 60-74.

Coffey RNT, Watson RWG, O’Neill AJ, McEleny K \& Fitzpatrick JM 2002 Androgen-mediated resistance to apoptosis. Prostate 53 300-309.

Curlewis JD, Tam SP, Lau P, Kusters DHL, Barclay JL, Anderson ST \& Waters MJ 2002 A prostaglandin $\mathrm{F}_{2 \alpha}$ analog induces suppressors of cytokine signaling-3 expression in the corpus luteum of the pregnant rat: a potential new mechanism of luteolysis. Endocrinology 143 3894-3993.

Delfino F \& Walker WH 1998 Stage-specific nuclear expression of NF-кB in mammalian testis. Molecular Endocrinology 12 1696-1707.

Delfino F \& Walker WH 1999 Hormonal regulation of the NF-кB signaling pathway. Molecular and Cellular Endocrinology 157 1-9.

Geymayer S \& Doppler W 2000 Activation of NF-кB p50/p65 is regulated in the developing mammary gland and inhibits STAT5-mediated $\beta$-casein gene expression. FASEB foumal 14 1159-1170.

Goyeneche AA, Deis RP, Gibori G \& Telleria CM 2003a Progesterone promotes survival of the rat corpus luteum in the absence of cognate receptors. Biology of Reproduction 68 151-158.

Goyeneche AA, Martinez IL, Deis RP, Gibori G \& Telleria CM $2003 b$ In vivo hormonal environment leads to differential susceptibility of the corpus luteum to apoptosis in vitro. Biology of Reproduction 68 2322-2330.

Jones PB, Valk CA \& Hsueh AJ 1983 Regulation of progestin biosynthetic enzymes in cultured rat granulosa cells: effects of prolactin, beta 2-adrenergic agonist, human chorionic gonadotropin and gonadotropin releasing hormone. Biology of Reproduction $29572-585$.

Jones PL, Ping D \& Boss JM 1997 Tumor necrosis factor $\alpha$ and interleukin- $1 \beta$ regulate the murine manganese superoxide dismutase gene through a complex intronic enhancer involving C/ERP- $\beta$ and NF-кB. Molecular and Cellular Biology 17 6970-6981.

Kawaminami M, Shibata Y, Yaji A, Kurusu S \& Hashimoto I 2003 Prolactin inhibits annexin 5 expression and apoptosis in the corpus luteum of pseudopregnant rats: involvement of local gonadotropin-releasing hormone. Endocrinology 144 3625-3631.

Krueger A, Schmitz I, Baumann S, Krammer PH \& Kirchhoff S 2001 Cellular FLICE-inhibitory protein splice variants inhibit different steps of caspase-8 activation at the CD95 death-inducing signaling complex. Fournal of Biological Chemistry 276 20633-20640.

Luo G \& Yu-Lee L 2000 Stat5b inhibits NFkappaB-mediated signaling. Molecular Endocrinology 14 114-123.

Lyss G, Knorre A, Schmidt TJ, Pahl HL \& Merfort I 1998 The anti-inflammatory sesquiterpene lactone helenalin inhibits the transcription factor NF- $\mathrm{KB}$ by directly targeting p65. Fournal of Biological Chemistry 273 33508-33516.
Manna SK \& Aggarwal BB 1999 Lipopolysaccharide inhibits TNF-induced apoptosis: role of nuclear factor-kB activation and reactive oxygen intermediates. Fournal of Immunology $\mathbf{1 6 2}$ 1510-1518.

Mao J, Duan WR, Albarracin CT, Parmer TG \& Gibori G 1994 Isolation and characterization of a rat luteal cDNA encoding 20 alpha-hydroxysteroid dehydrogenase. Biochemical and Biophysical Research Communications 20 11289-11295.

May MJ \& Ghosh S 1998 Signal transduction through NF-кB. Immunology Today 19 80-88.

Mercurio F \& Manning AM 2000 Regulation of NF-кB function. In Signaling Networks and Cell Cycle Control: the Molecular Basis of Cancer and Other Diseases, pp 429-438. Ed. JS Gutkind. Totowa, NJ: Humana Press Inc.

Orlowski RZ \& Baldwin AS Jr 2002 NF- $\mathrm{BB}$ as a therapeutic target in cancer. Trends in Molecular Medicine 8 385-389.

Quirk SM, Porter DA, Huber SC \& Cowan RG 1998 Potentiation of Fas-mediated apoptosis of murine granulosa cells by interferon- $\gamma$, tumor necrosis factor- $\alpha$, and cycloheximide. Endocrinology 139 4860-4869.

Risk M \& Gibori G 2001 Mechanisms of luteal cell regulation by prolactin. In Prolactin, pp 265-295. Ed. ND Horseman. New York: Kluwer Academic Publishers.

Siebenlist U, Franzoso G \& Brown K 1994 Structure, regulation and function of NF-кB. Annual Review of Cell Biology $10405-455$.

Stocco CO, Zhong L, Sugimoto Y, Ichikawa A, Lau LF \& Gibori G 2000 Prostaglandin F2 $\alpha$-induced expression of $20 \alpha$-hydroxysteroid dehydrogenase involves the transcription factor NUR77. Fournal of Biological Chemistry 275 37202-37211.

Stocco CO, Djiane J \& Gibori G 2003 Prostaglandin $\mathrm{F}_{2 \alpha}\left(\mathrm{PGF}_{2 \alpha}\right)$ and prolactin signaling: PGF2 $\alpha$-mediated inhibition of prolactin receptor expression in the corpus luteum. Endocrinology 144 3301-3305.

Sugino N, Nakamura Y, Takeda O, Ishimatsu M \& Kato H 1993 Changes in activities of superoxide dismutase and lipid peroxide in corpus luteum during pregnancy in rats. Fournal of Reproduction and Fertility 97 347-351.

Sugino N, Zilberstein M, Srivastava RK, Telleria CM, Nelson SE, Risk M, Chou JY \& Gibori G $1998 a$ Establishment and characterization of a simian virus 40-transformed temperature-sensitive rat luteal cell line. Endocrinology 139 1936-1942.

Sugino N, Telleria CM \& Gibori G $1998 b$ Differential regulation of copper-zinc superoxide dismutase and manganese superoxide dismutase in the rat corpus luteum: induction of manganese superoxide dismutase messenger ribonucleic acid by inflammatory cytokines. Biology of Reproduction 59 208-215.

Tamm I, Trepel M, Cardó-Vila M, Sun Y, Welsh K, Cabezas E, Swatterhwait A, Arap W, Reed JC \& Pasqualini R 2003 Peptides targeting caspase inhibitors. Fournal of Biological Chemistry 278 14401-14405.

Telleria CM, Parmer TG, Zhong L, Clarke DL, Albarracin CT, Duan WR, Linzer DI \& Gibori G 1997 The different forms of the prolactin receptor in the rat corpus luteum: developmental expression and hormonal regulation in pregnancy. Endocrinology $1384812-4820$.

Telleria CM, Goyeneche AA, Stocco CO, Tessier C, Frasor J \& Gibori G 2000 Involvement of nuclear factor-kappa B in the regulation of luteal function. Biology of Reproduction 62 (Suppl 1) 268 (abstract 412).

Vaskivuo TE, Ottander U, Oduwole O, Isomaa V, Vihko P, Olofsson JI \& Tapanainen JS 2002 Role of apoptosis, apoptosis-related factors and $17 \beta$-hydroxysteroid dehydrogenases in human corpus luteum regression. Molecular and Cellular Endocrinology 194 191-200.

Wang Y, Chan S \& Tsang BK 2002 Involvement of inhibitory nuclear factor-kB (NF-kB)-independent NFkB activation in the 
gonadotropic regulation of $\mathrm{X}$-linked inhibitor of apoptosis expression during ovarian follicular development in vitro. Endocrinology $1432732-2740$.

Wiest WG, Kidwell WR, Bologh K Jr 1968 Progesterone catabolism in the rat ovary: a regulatory mechanism for progestational potency during pregnancy. Endocrinology $82844-852$.

Wintergalen N, Thole HH, Galla HJ \& Schlegel W 1995 Prostaglandin-E2 9-reductase from corpus luteum of pseudopregnant rabbit is a member of the aldo-keto reductase superfamily featuring $20 \alpha$-hydroxysteroid dehydrogenase activity. European Fournal of Biochemistry $234264-270$.

Xiao CW, Ash K \& Tsang BK 2001 Nuclear factor-kB-mediated $\mathrm{X}$-linked inhibitor of apoptosis protein expression prevents rat granulosa cells from tumor necrosis factor $\alpha$-induced apoptosis. Endocrinology 142 557-563.

Xiao CW, Asselin E \& Tsang BK 2002 Nuclear factor kB-mediated induction of flice-like inhibitory protein prevents tumor necrosis factor $\alpha$-induced apoptosis in rat granulosa cells. Biology of Reproduction 67 436-441.

Xiao CW, Yan X, Li Y, Reddy SAG \& Tsang BK 2003 Resistance of human ovarian cancer cells to tumor necrosis factor $\alpha$ is a consequence of nuclear factor $\mathrm{kB}$-medicated induction of fas-associated death domain-like interleukin-1 $\beta$-converting enzyme-like inhibitory protein. Endocrinology 144 623-630.

Yamamoto Y \& Gaynor RB 2001 Therapeutic potential of inhibition of NF- $\mathrm{KB}$ pathway in the treatment of inflammation and cancer. Fournal of Clinical Investigation 107 135-142.

Zhong L, Parmer TG, Robertson MC \& Gibori G 1997 Prolactin-mediated inhibition of $20 \alpha$-hydroxysteroid dehydrogenase and the tyrosine kinase system. Biochemical and Biophysical Research Communications 235 587-592.

Zhong L, Ou J, Barkai U, Mao JF, Frasor J \& Gibori G 1998 Molecular cloning and characterization of the rat ovarian 20a-hydroxysteroid dehydrogenase gene. Biochemical and Biophysical Research Communications 249 797-803.

Zhou HR, Islam Z \& Pestka JJ 2003 Kinetics of lipopolysaccharide-induced transcription factor activation/inactivation and relation to proinflammatory gene expression in the murine spleen. Toxicology and Applied Pharmacology 187 147-161.

Received in final form 13 November 2003 Accepted 19 November 2003 